Working Paper/Document de travail

2007-43

\title{
Price Discovery in Canadian and U.S. 10-Year Government Bond Markets
}

by Bryan Campbell and Scott Hendry 
Bank of Canada Working Paper 2007-43

August 2007

\title{
Price Discovery in Canadian and U.S. 10-Year Government Bond Markets
}

by

\author{
Bryan Campbell ${ }^{1}$ and Scott Hendry ${ }^{2}$ \\ ${ }^{1}$ Concordia University \\ Montréal, Quebec, Canada H3A 2A5 \\ and CIRANO, CIREQ \\ bryan.campbell@cirano.qc.ca \\ ${ }^{2}$ Financial Markets Department \\ Bank of Canada \\ Ottawa, Ontario, Canada K1A 0G9 \\ shendry@bankofcanada.ca
}

Bank of Canada working papers are theoretical or empirical works-in-progress on subjects in economics and finance. The views expressed in this paper are those of the authors.

No responsibility for them should be attributed to the Bank of Canada. 


\section{Acknowledgements}

Discussions with Greg Bauer, Chris D’Souza, Silvia Gonçalves, Ingrid Lo, Bruce Mizrach, and the seminar participants at the 2006 Bank of Canada Conference on Fixed Income Markets and the 2006 NFA Meetings are greatly appreciated. Any remaining errors are our own. 


\begin{abstract}
This paper presents some new results on the price discovery process in both the Canadian and U.S. 10-year Government bond markets using high-frequency data not previously analyzed. Using techniques introduced by Hasbrouck (1995) and Gonzalo-Granger (1995), we look at the relative information content of cash and futures prices in the market for Canadian Government bonds using futures market data from the Montreal Exchange and OTC cash market data reflecting the inter-dealer market covered by CanPx. We also analyze similar data from the US market over a somewhat longer period using data on the Chicago Board of Trade (CBOT) futures market as well as the cash market from GovPx in the first part of the sample and subsequently from BrokerTec.

In general, we find that relatively more price discovery occurs in the futures markets than the cash markets in both Canada and the U.S. and that the results look remarkably similar across the two countries despite the large differences in the sizes of their markets and in their characteristics, particularly on the cash side. These overall results, however, hide the fact that information shares for the U.S. futures markets declined throughout 2004-05 apparently as a result of improvements in the spot market BrokerTec platform. Day-to-day variation in price discovery information shares is related to bid-ask spreads, trading volumes, and realized volatility in the markets but there remains much unexplained.

JEL classification: G12, G13, G14

Bank classification: Financial markets; Market structure and pricing
\end{abstract}

\title{
Résumé
}

Mettant à profit des données de haute fréquence qui n'avaient pas été analysées jusqu'alors, l'étude présente de nouveaux résultats concernant le processus de découverte des prix sur les marchés canadien et américain des obligations d'État à dix ans. Au moyen de techniques élaborées par Hasbrouck (1995) et Gonzalo-Granger (1995), les auteurs examinent les contenus informatifs respectifs des prix au comptant et à terme pratiqués sur le marché des obligations du gouvernement canadien, à la lumière des données de la Bourse de Montréal sur les contrats à terme et des données de CanPX sur les opérations de gré à gré au comptant conclues sur le marché intercourtiers. Ils analysent également des informations similaires pour le marché américain, sur une période un peu plus longue, en se fondant sur les données du Chicago Board of Trade concernant les contrats à terme et sur les données relatives au marché au comptant provenant de GovPX, pour la première partie de l'échantillon, et de BrokerTec pour le reste de celui-ci. 
Dans l'ensemble, les auteurs constatent que le marché à terme contribue davantage à la découverte des prix que le marché au comptant, tant au Canada qu'aux États-Unis, et que les deux pays présentent des résultats remarquablement similaires malgré les tailles et les caractéristiques sensiblement différentes de leurs marchés respectifs, en particulier dans le cas du marché au comptant. Ces résultats masquent toutefois le fait que la contribution des marchés à terme américains à la découverte des prix a diminué tout au long de 2004-2005, par suite apparemment des améliorations apportées à la plateforme de négociation BrokerTec pour les opérations au comptant. Les variations quotidiennes de la contribution de chacun des deux marchés sont liées aux écarts acheteur-vendeur, aux volumes de transactions et à la volatilité réalisée sur les marchés, mais elles demeurent inexpliquées dans une large mesure.

Classification JEL : G12, G13, G14

Classification de la Banque : Marchés financiers; Structure de marché et fixation des prix 


\section{Introduction}

This paper presents some new results on the price discovery process in both the Canadian and U.S. 10-year Government bond markets. We look at the relative information content of cash and futures prices in the market for Canadian Government bonds using futures data from the Montreal Exchange and OTC cash data reflecting activity in the inter-dealer market covered by CanPx, a consolidation of screen-based, inter-dealer voice brokers. The paper also examines price discovery across futures and spot markets for the U.S. Open pit and electronic market trading data for the 10-year Treasury note come from the Chicago Board of Trade (CBOT) while spot market data comes from GovPx, a consolidator of inter-dealer voice brokers, and BrokerTec, the dominant electronic inter-dealer broker platform. This paper has two main contributions. The first is the within-country comparison of price discovery across futures and cash markets for Government debt which has received limited attention in the literature and none using the BrokerTec data which is the most up-to-date available. The second main contribution is the U.S.-Canadian comparison which is interesting given that Canadian markets are much smaller, with less trading and wider spreads, and that the inter-dealer brokered market is still largely voice-based.

We follow the information-share approaches introduced by Hasbrouck (1995) and GonzaloGranger (1995) building on the ideas of Booth et al. (1999) to evaluate contributions of trading in the cash and futures markets to the price discovery process. The two approaches work in a vector error correction model but offer alternative methodologies for separating long-run price movements from short-run market microstructure effects. Both techniques are used to offer a robust analysis and because each has its advantages and disadvantages. As well, we determine size and temporal measures of market adjustment to equilibrium during the price discovery process in the spirit of those introduced by Yan and Zivot (2004).

We find that, on average over the full sample, about $70 \%$ of price discovery occurs on the futures markets in both Canada and the U.S. Similarly, the futures markets have smaller cumulative deviations from new fundamental values following shocks and are also able to find these new values significantly quicker. It is also revealed, however, that over the last two years of the 
sample (2004-05) the contribution of the U.S. futures market to price discovery has been declining despite a number of changes that have been made to improve the quality of that market. Improvements in the electronic trading platform in the spot market seem to be drawing price discovery away from the futures market through increased volume and lower spreads. At the end of 2005 , about $50-60 \%$ of price discovery was on the U.S. electronic spot market. The Canadian results were relatively more stable but there were also fewer changes and shocks to the trading systems. The Canadian spot market has maintained a sizeable contribution to price discovery, about 30\%, despite being compared to a growing electronic exchange-based market.

The paper is organized as follows. We present a brief review of the antecedent literature on price discovery in section one. Section two surveys the econometric methodology employed in the paper while section three introduces the various markets considered in this study. Section four presents some descriptive statistics for the individual markets followed by section five which relates the main empirical results of the paper. Price discovery information share and impulse response measures are computed and compared across the markets. Section six discusses the determinants of the information shares and the final section offers some conclusions.

\section{Related Literature}

Price discovery refers to the process through which financial markets converge to the efficient price of the underlying asset. Theoretically when two similar markets for the same product are faced with the same information arriving simultaneously, the two markets should react at the same time in a similar fashion. When the two markets do not react at the same time, one market will then lead the other. When such a lead-lag relation appears, the leading market is viewed as contributing a price discovery function for that sector. Price discovery has been and continues to be an active field of research. The following researchers have looked at this question using a number of different cash and futures markets; in particular, Garbade and Silber (1982) looked at commodity futures, Stoll and Whaley (1990), Chan (1992) examined U.S. stock index futures, Grunbichler, Longstaff, and Schwartz (1994) studied German stock index futures, Poskitt (1999) has studied New Zealand interest rate futures, Upper and Werner (2002) examined German Bund 
Markets, and Mizrach and Neely (2005) analyzed the U.S. Government bond markets. Finally, Campbell, Chung, and Hendry (2007) completed a preliminary analysis of the Canadian 10-year Government bond markets that serves as a starting point for this paper. A full description of the recent literature on the information share and price discovery literature can be found in Campbell, Chung, and Hendry (2007). This section will only relate some of the highlights from this work.

Microstructure research typically finds that the futures market leads the cash market and contribute more to the price discovery process. The principle explanation for this is that futures markets generally have relatively lower transaction costs given that they are typically exchange based as opposed to over-the-counter markets. The trading cost hypothesis of price leadership that predicts that the market with the lowest overall trading cost will react most quickly to new information (see Fleming, Ostdiek, and Whaley, 1996).

As we have suggested, a number of different methodologies have been used to determine the time difference in the lead-lag relationship. In this paper, we will focus on the information share methodologies of Hasbrouck (1995) and Gonzalo and Granger (1995). Hasbrouck (1995) is based on the assumption of an efficient price common to both the futures and cash market and characterizes a market's contribution to price discovery - its information share - as the "proportion of the efficient price variation that can attributed to that market." (p. 1177). Hasbrouck has argued that the appropriate econometric context for the analysis is supplied by the vector error correction model (Stock and Watson, 1988). Another approach is supplied by the identification of long-memory common factors suggested by Granger and Gonzalo (1995). The relative merits of the two approaches are the subject of some discussion; a special issue of the Journal of Financial Markets (2002) is devoted to the topic. While much of the previous literature has examined on equity markets, our focus is on fixed-income markets.

Upper and Wener (2002) is very much in the spirit of our contribution. They examine price discovery between the German Bund futures and spot markets during 1998. They find that between $67 \%$ and $81 \%$ (using the Hasbrouck methodology) or about $83 \%$ (using the Gonzalo- 
Granger methodology) of price discovery occurred in the futures market during the relatively normal times of the first half of 1998. However, during some of the more volatile periods in the second half of 1998, particularly around the time of the LTCM crisis, the share of price discovery of the spot market fell to near zero. They claim this is consistent with anecdotal evidence they have that during stress periods spot trading simply follows the futures markets.

A recent addition to the literature is Mizrach and Neely (2005) who use the Hasbrouck and Granger-Gonzalo information shares to investigate bivariate price discovery across different cash and futures markets for U.S. Government bonds of different maturities. An innovation in this paper is the study of price discovery in a system of futures and cash bond prices of different maturities. For 10-year bond data, the cash market dominated price discovery from 1995 to 1999 with an information share above 50\%. However, in 2000 the cash market information share dropped significantly and the futures market began to dominate price discovery. In the full specification combining different maturities, it was found that trading in the 5 year bond cash market and the 30-year bond futures market dominated price discovery.

A recent paper examining price discovery across markets by Yan and Zivot (2004) assesses the efficiency of price discovery by the magnitude of pricing errors given by impulse response functions of the reaction to a permanent shock to the efficient price. Their methodology is similar in spirit to Hasbrouck (2003) but takes it a step further to measure numerically deviations from the efficient price. They apply their methodology to the case of price discovery for the JPY/EUR exchange rate by comparing the prices in the direct trading market to the markets for indirect implied trading via USD/EUR and JPY/USD. They find that substantial price discovery occurs through the USD markets due to the much greater degree of liquidity available in these markets. The relative liquidity and lower transaction costs of the USD markets are conducive to the efficient assimilation of dispersed economy-wide information.

One other recent paper is worth mentioning even though it does not use the information share methodology. Brandt et al (2006) investigates price discovery across four U.S. Treasury cash and futures markets, the 2-, 5-, 10-, and 30-year, for the period from 1995-2000 using GovPx and CBOT data. They find that net order flow has significant explanatory power for price dynamics 
in both cash and futures markets. In particular, net order flow in two and five-year spot markets and in the futures markets by exchange members and retail traders is important for both cash and futures market price discovery. Overall, they find important cross-market interactions in the price discovery process. The current paper does not focus on the contribution of order flow to price discovery but instead focuses on a much more up-to-date sample, uses a different methodology, and makes an international comparison. The role of order flow in the price discovery process will be the focus of future work.

The current paper extends earlier work in Campbell, Chung, and Hendry (2007) which estimates information shares for only the 10-year Government bond futures and spot markets. That paper estimated information shares using basic OLS, as have previous papers, as well as a GARCH specification in an attempt to control for the obvious presence of heteroskedasticity. Futures market information shares were found to be about $70 \%$, or slightly lower when using a GARCH model. The current paper estimates a more unrestricted version of the VECM from Campbell, Chung, and Hendry (2007) and makes the comparison to the U.S. results.

\section{Price Discovery Across Markets}

Both the Hasbrouck and Gonzalo-Granger approaches to price discovery feature a decomposition of price movements into a permanent, non-stationary component and a transitory component. Although ultimately related, the two approaches differ on how the permanent component is identified. With the Hasbrouck approach, the permanent component is a martingale and accordingly reflects features of efficient market behaviour. By contrast, the non-stationary component in the Gonzalo-Granger approach may be forecastable. Our intent is not to comment on the relative merits of the two approaches. There appears to be some consensus in the literature that both are useful. Here we outline the essential components of the two approaches. For further details on these specifications, it should be noted that a recent issue of the Journal of Financial Markets (2002) describes and assesses the two approaches in some detail. 
Assume that a particular asset is traded in $N$ different markets with I(1) prices represented by $p_{i t}$ for $I=1, \ldots, N$. Suppose the prices are cointegrated and have an $r^{\text {th }}$ order VAR representation in levels. Such a specification can be converted into a first difference or return VECM as follows:

$$
\Delta p_{t}=\alpha \beta^{\prime} p_{t-1}+\sum_{j=1}^{r-1} B_{j} \Delta p_{t-j}+v_{t},
$$

where $p_{t}$ is a vector of the $N$ prices, $v_{t}$ is an error vector with covariance matrix $\Omega$, and $\alpha$ (NXR), $\beta$ (NXR), and $B_{j}(1 \mathrm{XN}$ ) are parameters to be estimated (with R being the number of cointegrating vectors among the $\mathrm{N}$ prices). The error correction term $\beta^{\prime} p_{t}$ has rank $R=N-1$ since all the prices in the $N$ different markets are cointegrated and will move together over time. This vector of error correction terms is given as

$$
\beta^{\prime} p_{t-1}=\left[\begin{array}{c}
p_{1, t-1}-\beta_{2} p_{2, t-1} \\
\vdots \\
p_{1, t-1}-\beta_{N} p_{N, t-1}
\end{array}\right]
$$

Some previous studies have chosen to assume $(1,-1)$ cointegrating vectors between prices in different markets, especially when the assets involved are equity based. ${ }^{1}$ However, it can be argued that spot and futures bond prices are not directly comparable so a more general specification should be allowed. In this paper, we adopt the more general specification in (2), as do Mizrach and Neely (2005), to account for effects coming from the conversion factors applied to the different bonds in the basket of deliverables for the futures contract and from intraday movements in the prices on repo transactions, which are often used to finance bond positions.

The adjustment coefficients in $\alpha$ govern the speed at which prices respond to disequilibria in the prices between markets. As $\alpha_{j}$ ? 0 the price in market $j$ responds less to a disequilibrium between

\footnotetext{
${ }^{1}$ Chung, Campbell, and Hendry (2007) assume a $(1,-1)$ cointegrating relationship between raw spot and futures prices while Upper and Werner (2002) assume the same cointegrating vector between futures prices and spot prices adjusted for an estimated cost of carry.
} 
markets implying that market $j$ tends to lead, not follow, and that it accounts for more of the price discovery for the underlying asset.

The Hasbrouck (1995) approach follows Stock and Watson (1988) to decompose prices into their permanent and transitory components. After rewriting (1) in moving average form, $\Delta p_{t}=C(L) v_{t}$, some algebra can generate an expression for the price level that has a permanent and transitory component:

$$
p_{t}=C(1) \sum_{k=1}^{t} v_{k}+\widetilde{C}(L) v_{t}+p_{0}
$$

where $\mathrm{C}(\mathrm{L})$ and $\widetilde{C}(L)$ are matrix polynomials in the lag operator $\mathrm{L}$. The first term is the permanent component while the second is the transitory. $\mathrm{C}(1)$, the sum of the moving average coefficients, has identical rows due to cointegration between the prices. Baille, Booth, Tse, and Zabotina (2002) show that

$$
C(1)=\beta_{\perp} \pi \alpha_{\perp}^{\prime}=\pi\left[\begin{array}{ccc}
c_{1} & \cdots & c_{N} \\
\vdots & & \vdots \\
c_{1} & \cdots & c_{N}
\end{array}\right],
$$

where $\pi$ is a scalar factor and $\alpha_{\perp}$ and $\beta_{\perp}$ are orthogonal complements of the parameters in (1).

If $c=\left[\begin{array}{llll}c_{1} & \ldots & c_{N}\end{array}\right]$, then the permanent contribution of the innovation vector $v_{t}$ to the price is $c v_{t}$ with variance given by $c \Omega c^{\prime}$, where $\Omega$ is the covariance matrix of $v_{t}$. Since $\Omega$ is typically not diagonal, Hasbrouck proposes using a Choleski factorization of $\Omega$ to find the lower triangular matrix $F$ such that $F F^{\prime}=\Omega$. The Hasbrouck information share for market $j$ is then defined as:

$$
I_{j}=\frac{\left[\sum_{i=1}^{N} c_{i} F_{j i}\right]^{2}}{c \Omega c^{\prime}}
$$

which is the proportion of the variance of the permanent component of prices coming from market $j$. The Hasbrouck information shares are the result of an infinite horizon variance decomposition of the prices in the $N$ markets. Since the Choleski decomposition depends on the ordering of the variables in the covariance matrix, the Hasbrouck information share is not unique. Upper and lower bounds on the information share are calculated from all possible orderings of the variables. 
The second measure of information shares is based on Harris, McInish, Shoesmith, and Wood's (1995) application of the Gonzalo and Granger (1995) common factor approach to the decomposition of prices into their permanent and transitory components. Under this approach, prices are determined as follows:

$$
p_{t}=W f_{t}+\widetilde{p}_{t}
$$

with $f_{t}$ the non-stationary permanent component and $\tilde{p}_{t}$ the stationary transitory component. Identification is achieved by imposing two conditions. The first stipulates that $f_{t}$ is a linear combination of the current prices $p_{t}$ (i.e. that $f_{t}=\Gamma p_{t}$ ) while the second assumes that the transitory component does not Granger-cause the permanent component. If the factor weights are normalized so that they sum to one, then they can be interpreted as the contributions of the prices to the permanent component. Gonzalo and Granger (1995) showed that the vector of factor weights $(\Gamma)$ is orthogonal to the vector of error correction term loadings $(\alpha)$ in (1). In other words, $\alpha_{\perp}=\Gamma^{\prime}$. This implies that the factor weights and GG information shares in a bivariate example are given by

$$
\gamma_{1}=\frac{\alpha_{2}}{\alpha_{2}-\alpha_{1}} \quad \text { and } \quad \gamma_{2}=\frac{\alpha_{1}}{\alpha_{1}-\alpha_{2}}
$$

In short, the differences between the two approaches relate to the martingale feature of the Hasbrouck approach contrasted with the Gonzalo-Granger approach, and the fact that along with the weights associated with the error-correction adjustment the Hasbrouck approach considers as well the variances of the underlying innovations. These points are emphasized in Baillie et al (2002).

One final point to note is that the Hasbrouck information share is bounded by [0,1] by construction. The GG measure, however, sums to one across the two markets but is not necessarily bounded by the $[0,1]$ interval. As such, there are examples in our day-by-day 
estimation for which the GG information share is outside the $[0,1]$ interval and thus quite difficult to interpret.

The Canadian case will compare price discovery across two markets, the electronic futures market for the CGB and the inter-dealer brokered market covered by CanPx. For the U.S., price discovery information shares will be investigated across three markets, the futures pit at the CBOT, electronic futures trading also at the CBOT, and electronic inter-dealer trading via BrokerTec.

Another manner in which price discovery has been studied recently is to examine the shape of the impulse response functions in each market following a shock. Hasbrouck (2003) performed visual inspections of the response functions to get a flavour for the speed of convergence across markets. Yan and Zivot (2004) formalized this methodology by computing the cumulative pricing errors during the price discovery process. Some preliminary technical remarks are in order.

According to this approach, we first compute the cumulative difference between the impulse response value in each period and the value to which it converges in the long-run. Since structural shocks are identified via Choleski decompositions, it follows that there are four impulse responses for each of two decompositions in the bivariate case (two variables responding to two shocks according to two decompositions). Within each decomposition, the cumulative sums are then weighted by the share of the asymptotic variance decomposition for that market and shock (i.e., the futures market response to a cash market shock is weighted by the contribution of the cash market to futures market volatility in the long run). In turn, each Choleski decomposition is equally weighted. The result is a cumulative pricing error. Higher values of the error imply slower convergence to the new long-run equilibrium value following a shock; in other words, there is slower price discovery in that market.

In this paper we have used another statistic that is perhaps easier to interpret than the cumulative pricing error in the previous impulse-response analysis. We determine, for each shock, the number of periods it takes the cash and futures market to return to equilibrium, or more 
precisely, to within a close approximation (10\%) of equilibrium. The estimates for each impulse response were weighted in the same manner as above to yield an average number of periods until convergence. Accordingly, we then have a simple time measure of the relative efficiency of the two markets in processing new information.

All of the estimation in this paper was done using OLS. The VECM models estimated using Canadian data and the bivariate U.S. model with GovPx data assumed two lags based on the average across the daily results of different information criteria. The U.S. trivariate models with two futures markets and a spot market assumed six lags.

\section{10-Year Spot and Futures Data in Canada and the U.S.}

\section{Canadian Data}

The source for the spot market data for the Government of Canada 10-year bond is Moneyline Telerate's CanPx system. A detailed analysis of liquidity in this market can be found in D'Souza, Gaa, and Yang (2003). CanPx is a data service that consolidates and disseminates trade and quotation data submitted by Canada's fixed-income screen-based inter-dealer voice brokers. Over the sample period, the four Canadian inter-dealer brokers (IDB) are Freedom International Brokerage Company, Prebon Yamane (Canada) Ltd., Shorcan Brokers Limited, and Tullett Liberty (Canada) Ltd. CanPx was introduced by the IDBs and securities dealers on August 20, 2001 with a view to enhancing the degree of transparency in the Government bond market. Although in operation since 2001, there are two large breaks in the sample, from September 2001 to February 2002 and from March to September 2003; the data has not been archived. The sample used for this paper covers the period from February 26, 2002 to February 25, 2003 and November 27, 2003 to February 27, 2004.

Quotes posted at an IDB are firm commitments to trade at the specified price. The volume, however, can be 'worked up' through negotiations between the buyer and seller once a trade is initiated. The CanPx data amalgamates all the trade and quote data presented on the screens of the four IDBs from approximately 0700 to 1800 each day. Only the best bid and offer quotes 
from across the four IDBs are presented to CanPx customers and stored. For information on how this data was cleaned, see Campbell, Chung, and Hendry (2007).

Roughly $55 \%$ of the Canadian secondary spot market was customer-dealer trade in 2002, while $46 \%$ was inter-dealer trading. Of the inter-dealer trading, $86 \%$ was through IDBs with the remainder being direct dealer to dealer trade. The CanPx data is relatively complete in that it records the best bid and offer quotes as well as all trades from all four of the Canadian IDBs.

In September 1989, the Montreal Exchange introduced a futures contract on the 10-Year Government of Canada Bond to trade under the ticker symbol CGB. ${ }^{2}$ At any given time there are up to eight contracts available for trading corresponding to four maturity dates per year over two years. The vast majority of trading volume takes place on the front-month contract. Trading in the next-to-deliver contract usually increases only after the first notice day for the currently traded contract. In this study we have rolled over contract maturities when volume on the nextto-deliver contract surpasses the volume on the front-month contract.

In September 2000, the Montreal Exchange moved from a traditional open outcry system to an automated electronic system. Intraday transactions for the CGB are available since October 22, 2001. This study only considers data from the daily open continuous trading session that runs from 8:20 a.m. to 3:00 p.m. In this data set, a recorded quote represents the best bid/offer spread at the time of recording and is maintained until a subsequent quote is entered.

Seven complete contracts fall within the purview of the Canadian portion of this study. In general, the trading days associated with a specific contract run until one to three days after the first notice of the contract. The cutoff is determined at the point where the volume for the next contract exceeds that of the current contract. Days with early closures before holidays, greater than two hours with no price update (typically signaling a technical problem with the recording of data), and with more than one minute of missing data at the beginning of the day are excluded. All told there are 385 trading days in the sample.

\footnotetext{
${ }^{2}$ Further information on the CGB contract on the Montreal Exchange can be found in Campbell and Chung (2003).
} 
Since firm bid and ask quotes are available for both Canadian markets, the mid-point of the bid and ask prices is used as the fundamental variable to be modeled. There are considerably more frequent quote updates throughout the day than there are transactions so this focus on quotes allows for a data set with much richer and more realistic price dynamics. Only data on the 10year benchmark bond are used. ${ }^{3}$ The data are sampled at 30-second intervals implying 800 observations per day. 30 seconds was approximately the average duration between quote updates on the futures market. Finally, based on results from various information criteria, the VECM was estimated with two lags for each day in the sample.

\section{US Data}

There are two sources of spot market data for the U.S. Government 10-year bond. The first is GovPx, a consolidation service for the voice-brokered inter-dealer market. It was founded in 1990 by the dealer and inter-dealer broker community in response to concerns among government authorities that there was insufficient price transparency in the U.S. Treasury market. Quote and trade information from three inter-dealer brokers - Garban-Intercapital, Hilliard Farber, and Tullett \& Tokyo Liberty - are combined into a single source that is marketed in real-time to fixed-income professionals. Only one major inter-dealer broker, Cantor Fitzgerald, is not a contributor, an omission that is only considered a problem in the 30-year Treasury bond market. The data used in this study runs from January 2000 to the end of May 2001 in order to use the latest data possible, and because trading through GovPx brokers drops significantly beginning in 2001 quite possibly due to the advent of alternative electronic trading systems. Transaction price data is used to match the available futures data. The data is for the onthe-run bond.

Subsequent spot market data originates with BrokerTec, an inter-dealer electronic trading platform of secondary wholesale U.S. treasury bonds that currently has a market share of approximately $60-65 \%$ of the active issues. While BrokerTec does still offer voice-broker services, the data available is for its electronic platform and comprises the vast majority of its

\footnotetext{
${ }^{3}$ The cheapest-to-deliver bond from the basket of bonds supporting the futures contract is often not the benchmark bond. Spot market quoting and trading on the off-the-run bonds, however, is too thin in Canada to give a consistently reliable measure of pricing.
} 
activity. Its success since it opened for business in June 2000, as well as that of other electronic competitors, is one of the main reasons for the decline in trading reported through GovPx. The BrokerTec platform increased its market share substantially during the sample under study by offering a fast and efficient trading system that was kept state-of-the-art.

BrokerTec functions as a limit order book and operates from 7:00 pm until 5:30 pm EST the next day. Data on the full order book is available but only transactions prices will be used in this study to match data available from the futures market. The intraday data is available from April 8, 2002 until December 31, 2005. Only data for the on-the-run issue from the open hours of the futures pit (8:20 a.m. to 3:00 p.m. EST) will be used.

The U.S. 10-year treasury futures contract is primarily traded on the Chicago Board of Trade (CBOT). The CBOT only provides transaction price and volume data. The data used spans January 2000 to December 2005. Electronic trading on the CBOT began in August 2000 while pit trading began in 1977. Pit trading is open from 8:20 am to 3:00 pm EST, while electronic trading runs from 8:00 pm one day to 5:00 pm the next day EST. Data for both futures markets is used but only for the period from 8:20 - 3:00 when the pit is open. There are four contracts per year with maturities in March, June, September, and December; the same as in Canada. The data rolls from one contract to the next when daily trading on the $1^{\text {st }}$ back contract surpasses trading on the front contract.

There were a number of changes to the CBOT trading environment during the sample period. In January 2004, the CBOT adopted the clearing system of the Chicago Merchantile Exchange (CME) which allowed its members, particularly those who are also CME members, to save some $\$ 1.8$ billion in risk capital. At the same time, the CBOT adopted the electronic trading platform of LiffeConnect from Euronext which substantially improved trading speeds. One of the main reasons for these changes was the impending entry to the Treasury futures market of Eurex. On February 8, 2004, Eurex began trading Treasury futures in the U.S. in direct competition with the CBOT. In response, the CBOT improved its clearing system and trading platform as well as lowered its trading fees by over $75 \%$. While trading on Eurex began reasonably well, about a $5 \%$ market share in its first week, it never became a significant competitor for the CBOT and its 
share fell to less than $2 \%$ after only a few weeks. Eurex ceased trading Treasury futures contracts in June of 2005. After Eurex exited the market, trading fees were raised once again in the latter half of 2005 in conjunction with an upgrade to its electronic trading platform. 2005 also saw the imposition of position limits for the last ten days of trading of its Treasury futures contracts. Traders were restricted to hold less than 50000 10-year futures contracts starting with the December 2005 contract. This action was taken after the amount of 10-year contracts settled through physical delivery reached record levels for the March and June 2005 contracts. The CBOT set these limits to improve contract performance and ensure the integrity of the market, but it was not a universally popular change among the larger players. All of these changes could have had a substantial effect on the price discovery process. The improvements in the trading framework at the CBOT would likely have increased price discovery on the futures market, while the increased competition from Eurex and increased fees could have driven price discovery away.

As with the Canadian sample, only full days are considered. Days with early closures before a holiday or significant periods of missing data are excluded. Days with more than one minute of missing data at the start of the day (8:20) are also omitted to ensure sufficient data was available before the 8:30 typical macro news announcement time. For the GovPx sample, days with fewer than 30 trades are excluded. Similarly, the GovPx sample is terminated at May 29, 2001 due to long periods of inactivity in the subsequent period. This leaves seven contracts of data covered by GovPx and 15 contracts of data covered by the BrokerTec sample. As mentioned, transaction prices are used instead of quotes because quotes are not available for the futures market. The data is sampled at a 5-second interval when using the BrokerTec data but at a 30-second interval when using the GovPx data. Finally, based on information criteria test, the VECMs were estimate with two lags for the GovPx bivariate system and six lags for the trivariate systems. ${ }^{4}$

To sum up, the paper will compare price discovery in Canada for an electronic futures market and a screen-based inter-dealer voice brokered spot market to the U.S. for an open pit futures market, and electronic futures market, and an electronic inter-dealer brokered spot market.

\footnotetext{
${ }^{4}$ A specification with longer lags was also estimated for the BrokerTec system but the results were qualitatively and quantitatively similar.
} 


\section{Descriptive Statistics}

Before presenting the price discovery information shares, Tables 2 and 3 provide a basic description of trading activity and bid/ask spreads across all of the markets. Further background information on the Canadian markets is contained in Campbell, Chung, and Hendry (2007)

The CGB market saw the average daily number of trades increase from about 540 trades for the June 2002 Contract to just over 950 trades in the September 2004 contract period (see Table 2). This represented a daily total volume increase from about 5250 contracts to 7300 contracts. The average daily trade size, however, fell from about 9.8 contracts to about 7.8 contracts. With a notional value of $\$ 100,000$ per contract this implies an average trade size of less that $\$ 1$ million and a total daily notional volume of over $\$ 700$ million. In contrast, in the inter-dealer spot market in June 2002 there were only about 30 to 40 trades each day representing just over $\$ 160$ million in total daily volume. The average daily trade size fell from about $\$ 4.7$ million during the June 2002 Contract period to about $\$ 4.3$ million during the September 2004 contract period. The interdealer spot market trading through IDBs has many fewer trades per day but each trade is much larger. The futures market is four to five times the size of the spot market considered here in terms of the value of daily volume traded.

The belief is that trading costs are generally lower on futures markets than on spot markets. The bid-ask spread, while an imperfect measure, gives a good indication of the level of transaction costs in the markets. Over the sample, the percentage bid-ask spread has fallen in the CGB market from about 4.84 basis points for the June 2002 Contract to 2.67 basis points in the September 2004 Contract (see Table 3). ${ }^{5}$ At the same time, the spot market spread fell from 7.20 to 5.65 basis points. Both markets experienced reduced trading costs over the sample but, in each case, the CGB spreads were smaller by about $40 \%$ or more. This represents a potentially substantial savings for traders and a strong expectation for more price discovery in the futures market than in the spot market.

\footnotetext{
${ }^{5}$ The percentage bid-ask spread is calculated as spread $=[$ Pask-Pbid] $]([$ Pask + Pbid $] / 2)$
} 
The level of trading activity is much higher in the U.S. cash and futures markets. The mean daily number of trades on the inter-dealer BrokerTec platform increased from about 970 for the period of the June 2002 contract to about 7827 for the December 2005 contract. During this same period, the number of trades on the CBOT electronic platform increased from about 12750 trades to a peak of almost 41000 trades during the December 2003 contract before falling back to about 13580 trades for the December 2005 contract. There was a significant break in the average daily number of trades following changes in the CBOT trading platform and clearing system on January 1, 2004. Futures trading in the CBOT pit reached its peak of 1550 trades per day during the September 2003 contract but fell to about 376 trades per day by the end of the sample. The number of futures trades each day fell after January 2004 but the number of contracts traded each day did not. As such, the average size of each trade increased substantially with the new futures trading platform from an average of about 12 to 38 contracts. ${ }^{6}$ There were fewer small trades of every size up to 20 contracts after January 2004 implying that the clearing changes and savings in risk capital did not lead to the entry of new small investors (possibly retail) but rather caused the larger investors to begin to trade in bigger blocks.

Liquidity, as indicated by (the inverse of) percentage bid-ask spreads, is higher in the U.S. than in Canada. Table 3 shows that, since the second half of 2003, the futures market spreads have been the lowest of all the markets at around 1.4 basis points. ${ }^{7}$ Note that the typical price during this period and the convention to quote in 1/64 increments jointly imply that the typical futures market bid-ask spread is only one tic. During the earlier part of the sample, bid-ask spreads for tine inter-dealer spot market covered by GovPx increased from 2.7 basis points to just over five basis points for the June 2001 contract period. BrokerTec spreads have fallen from above four basis points to about 1.7 basis points over the sample. This substantial reduction in the BrokerTec spreads represents an important relative improvement in trading costs for the spot market that could have a significant impact on price discovery.

\footnotetext{
${ }^{6}$ The median number of contracts per trade was five before January 2004 and ten afterwards.

${ }^{7}$ Note that, since there is only trade price data available for the U.S. futures market, only approximate or pseudospreads can be calculated for this market. The bid-ask spread is approximated by the mean trade price change whenever there was a price change. This measure will approximate the bid-ask bounce or the spread.
} 


\section{Price Discovery: Empirical Results}

The Gonzalo-Granger and Hasbrouck information shares are reported in Table 4 for the Canadian futures market and in Tables $5 \mathrm{a}-\mathrm{d}$ for the U.S. futures markets. The cash market information share is, of course, just one minus the futures market share. The information share numbers reported are averages of the daily estimated shares.

For the Canadian case, our main results use quote mid-points due to the greater frequency with which these prices are updated. Also reported, however, are results using transaction prices because that is what is used in the U.S. analysis. Over the full sample, about $67.7 \%$ of price discovery occurred on the futures market according to the GG methodology. The information share increased from $58.5 \%$ for the June 2002 contract to about $71.3 \%$ for the March 2004 contract. There was a marked increase in the information share of the futures market after the first contract but it was quite stable after that. A similar result is observed when following the Hasbrouck technique. Between 70.1\% and 80.8\% (mid-point of 75.5\%) of price discovery occurred on the futures market. The same pattern over the contracts is also observed. The volatility of the information shares is fairly high. For both sets of results, the standard deviation across the days is above 16 percentage points, revealing substantial day to day variation.

The point estimate for the futures market information share is greater than 0.5 on over $85 \%$ of days. Using bootstrap generated confidence intervals, we find that $51.4 \%$ and $36.1 \%$ of days, according to the GG and Hasbrouck results respectively, had futures market information shares significantly greater than one-half. Futures market shares that were significantly less than onehalf were only observed on $4.2 \%$ or $1.0 \%$ of days for the two techniques. Finally, the futures and cash market information shares were insignificantly different from 0.5 on $44.4 \%$ of days for the GG results and $62.9 \%$ for the Hasbrouck.

The results using the transactions prices instead of the mid-quote reveal more or less the same pattern but attribute a slightly smaller share to the futures market, 59.9\% when using the GG methodology and $71.9 \%-76.1 \%$ for Hasbrouck. The day-to-day variation when using the 
transaction data was higher which is also shown in the fact that only just over $20 \%$ of days revealed a futures market information share of greater than one-half.

In sum, it appears that about $70 \%$ of price discovery in the Canadian market for 10 -year government debt occurs on the futures market. These results are quite similar to those recorded in Campbell, Chung, and Hendry (2007) which estimated basically the same model but also imposed restrictions to ensure the GG information share was in the $[0,1]$ range and that the cointegrating vector between futures and cash market prices was (1, -1). Although these restrictions did have a substantial effect on certain days' results, they did not affect the overall or contract averages.

To provide a flavour for the overall results, Figure 1 plots the daily estimates for the GG information shares for the September 2004 contract based on both quote and trade data. The qualitative nature of the results for the other contracts is quite similar. We see that there is substantial day-to-day variability and, as is possible with the GG technique, that some days even go outside the $[0,1]$ range. $^{8}$ The mean information share for the futures market during this contract was $68.8 \%$ with almost $64 \%$ of the days being significantly above one-half. The results for the Hasbrouck bounds for the September 2004 contract can be found in Figure 2. Note that the bounds are fairly tight and generally above one-half. About $55 \%$ of days, however, have an information share range for the futures market that is not significantly different from 0.5 .

Price discovery for the U.S. market was investigated for the futures pit and the GovPx spot market for the period from January 2000 to May 2001. Information shares were also estimated for the futures pit, the electronic futures platform, and the GovPx spot market using the last three contracts of the GovPx sample, starting in September 2000 with the advent of electronic futures trading on the CBOT. Finally, information shares were calculated from April 2002 to December 2005 across the two futures markets and the electronic spot market covered by BrokerTec. The results for the GG information share in the two futures markets are presented in Table 5a. The GG information share for the spot market is, of course, just one minus the share(s) for the futures market(s). The Hasbrouck information shares are given in Table $5 \mathrm{~b}$ for the futures and spot

\footnotetext{
${ }^{8}$ The exclusion of days outside the $[0,1]$ range does not significantly change the results.
} 
markets. In a trivariate system, the Hasbrouck ranges do not sum to one (the point estimates computed for each Choleski ordering do sum to one), so the cash market information share is also given. ${ }^{9}$ but the Hasbrouck lower and upper bounds need not sum to one with more than two markets.

During the first sub-sample in 2000 and 2001, the futures pit accounted for an average of 62.6\% of price discovery when compared against the spot market covered by GovPx. The information share increased from $15.8 \%$ for the March 2000 contract to $85.6 \%$ for the June 2001 contract. The Hasbrouck information share revealed an overall average range of $68.8 \%$ to $74.4 \%$ and an increase during the sample from $23.5 \%-25.3 \%$ for the first contract to $90.5 \%-94.7 \%$ for the last. The very tight bands estimated by the Hasbrouck methodology may imply that the sampling frequency of 30 seconds may actually be too high for this sample. The increased share of price discovery attributed to the futures market is consistent with the decline in trading that occurred at the inter-dealer voice brokers covered by GovPx during 2000 and 2001.

Information shares are also calculated across the three markets - pit futures, electronic futures, and GovPx - for the sample from September 5, 2000 to May 29, 2001. Right from the beginning of electronic futures trading, that market contributed substantially to price discovery. By the end of the first week of trading, the electronic futures market was accounting for about $30-40 \%$ of price discovery each day. The average GG information share over the first contract was $38.8 \%$ while the Hasbrouck share was $14-56 \%$. This proportion continued to rise so that by the June 2001 contract the average information shares were $47 \%$ and $17-77 \%$ for the GG and Hasbrouck, respectively. The futures pit was contributing 70\% of price discovery for the September 2000 contract which was the last contract before electronic futures trading began. The pit's information share fell to about $40 \%$ according to the GG methodology during the December 2000 contract implying that about three-quarters of the electronic futures market's information share came from the pit and about one-quarter from the spot market. Ideally, we would also like to add data from BrokerTec for this sample since it began operation in August 2000. However, that intraday data is not available.

\footnotetext{
${ }^{9}$ The point estimates computed for each Choleski ordering do sum to one but the Hasbrouck lower and upper bounds need not sum to one with more than two markets.
} 
Tables 5c and 5d contain the results when computing GG and Hasbrouck information shares, respectively, across the futures pit, electronic pit, and BrokerTec electronic inter-dealer spot market from April 2002 to December 2005. These results show about 16.2\% of price discovery in the futures pit, about $50.5 \%$ on the electronic futures market, and the remainder on the spot market when judging by the GG statistics. The Hasbrouck methodology revealed information share bands of about $5.7 \%-14.5 \%$ for the futures pit and $54.8 \%$ to $71.8 \%$ for the electronic futures market. The contract-by-contract results show that the information shares for both futures markets has declined over time. The futures pit has essentially declined steadily since the start of the sample, not surprising given the growth of electronic futures trading during that time. In addition, the information share for the electronic futures market has declined since the start of 2004. Until the end of December 2003, the electronic futures information share averaged $66 \%$ while from January 2004 until the end of 2005 the information share for this market was only $36 \%$. Before this break point, some $52 \%$ of days had an electronic futures market information share that was significantly greater than 0.5 while afterward there were $69 \%$ of days with an information share significantly less than 0.5. (Using Hasbrouck shares, the percentage of days significantly above 0.5 fell from $70 \%$ to $5 \%$.) This sharp decline coincided with changes that occurred in the underlying clearing and settlement system and the electronic trading platform at the CBOT on January 1, 2004. While these changes generated a significant savings in risk capital for firms trading on the CBOT, it seems that they may have also contributed to a decline in the amount of price discovery that occurred in the futures market. Recall from Table 1 that the number of trades on the futures markets declined post-January 2004 while trading on BrokerTec continued to explode. This decline in the number of trades may have contributed to the declining information share. This will be investigated further in the next section. The advent of futures trading on Eurex in February of 2004 may have also contributed to the declining information shares for the CBOT futures market over 2004 and 2005. The fact that the number of contracts traded on the CBOT did not decline, however, and that Eurex trading finally halted in June 2005 with no apparent increase in CBOT information shares suggests that competition from Eurex did not take a significant proportion of price discovery from the CBOT. 
Figures 4 and 5 plot the information shares for three example contracts: March 2003, March 2004, and December 2005. The beginning of the decline in the electronic futures market share can be seen toward the end of the March 2004 contract period while the December 2005 contract clearly shows a much lower information share. The daily volatility of the information shares is also quite apparent in the U.S. data much as it was in the Canadian results.

Table 6 combines the U.S. and Canadian results from Tables 4 and 5a-d, respectively, for only the contracts that are in common. The pit and electronic futures markets are combined for the U.S. to give the picture for the total futures market since there is only one futures market in Canada. The first four contacts show higher futures market information shares for the U.S. But starting with the March 2004 contract, there is a marked decline in the U.S. futures market price discovery share such that by the end of the sample it is substantially under the Canadian estimates. The greater information share for the futures market in Canada could be explained in part by the much higher level of activity on the BrokerTec spot market platform in the U.S. This is an electronic trading platform with a two-thirds market share for inter-dealer trading. This is in comparison to CanPx for Canada which is an amalgamation of screen-based voice-brokers for the inter-dealer market. Spot market electronic trading in the U.S. can deliver bid-ask spreads that are almost as low as for the futures market which may help explain how this market can be contributing more and more to price discovery over time as well as more than the Canadian spot market.

Tables 7 and 8 present results in the spirit of Yan and Zivot (2004). First, Table 7 reports the cumulative deviation from the new long-run value following shocks to the VECM while Table 8 uses the same impulse response functions to compute the average number of minutes needed to come within $10 \%$ of the long-run asymptotic value. ${ }^{10}$ Lower cumulative deviations and time until convergence to the long-run value imply a market is more efficient and exhibits greater price discovery. Also reported are the $5^{\text {th }}$ and $95^{\text {th }}$ percentiles across 1000 bootstrap simulations. The contract-by-contract results are shown for the Canadian case and the U.S. case using only the BrokerTec data given the greater reliability of these data. Only the average results are shown for

\footnotetext{
${ }^{10}$ Campbell, Chung, and Hendry (2007) also compute these statistics when examining the Canadian data but for a slightly different specification of the model.
} 
the GovPx sample period. Note that the Canadian and U.S. results are not directly comparable when considering the cumulative deviation from fundamental value because the sampling frequency is different in the two cases. The Canadian estimation is done with a 30 -second sampling interval while the U.S. estimation uses a 5-second interval. This will tend to make the U.S. cumulative sums larger by construction even if the path of convergence is identical. The estimates for the number of minutes until the fundamental value is reached (Table 8) are independent of the sampling frequency and, as such, are directly comparable across the two countries.

Both countries reveal cumulative deviations that are at least twice as large in the spot market as in the electronic futures market. For the U.S., deviations for the futures pit are between those of the electronic futures market and the spot market, and are significantly different from both. This finding mimics the information share results by implying that the majority of price discovery occurs on the futures market. The Canadian markets show declining cumulative deviations over the sample period as well as a declining difference between the markets. $39.5 \%$ of days showed spot market deviations that were significantly larger than for the futures market. Only $4 \%$ of days showed the reverse. The U.S. electronic futures market actually shows an increase in the deviations over the sample while the spot market shows a marked decline primarily in early 2004. Over the last seven contracts there is essentially no difference in the cumulative deviations for the spot and electronic futures markets.

Qualitatively similar results are seen in Table 8. The spot markets take significantly longer to reach the new long-run fundamental value following a shock. The U.S. took 5.7, 5.3, and 8.2 minutes on average for the pit, electronic futures, and spot markets, respectively, to discover the new fundamental prices. In Canada, the futures and spot markets took 6.1 and 9.7 minutes, respectively. The difference between the U.S. spot and electronic futures market disappeared beginning with the June 2004 contract. Since that time, there has been no significant difference between the two markets. For the common sample period, the Canadian markets took significantly longer to respond to shocks than the comparable U.S. market. Interestingly, however, the U.S. markets show a marked increase in the time taken for price discovery starting with the March 2005 contract period such that the latest observations are as high or higher than 
the older Canadian estimates. This latest increase in the U.S. reverses to some extent the declines in both the futures and spot market times that occurred in early 2004. These declines may be partly attributable to the changes in the futures trading framework at the CBOT in January 2004 but that does not explain why the spot market convergence times also declined. One final observation is that, despite the significant differences in the overall mean results, about $63 \%$ of days in Canada and 50\% in the U.S. show no significant differences in the convergence times for spot and electronic futures markets.

\section{The Determinants of Information Shares}

Table 9 presents the results of regressions that attempt to explain daily movements in the Gonzalo-Granger and Hasbrouck futures information-share measures in terms of various market features. These include the percentage bid/ask spread, the number of trades, and the realized volatility for the cash and futures markets. Realized volatility for a market is computed as the daily standard deviation of five-minute returns. Higher spreads in the futures market indicates higher trading costs or lower liquidity and should lead to less price discovery in the futures market. In contrast, higher spreads in the cash market should push informed trading toward the futures market and increase its information shares. A greater number of trades in the futures market indicate more liquidity and should raise the market's information share. More trading in the cash market will draw price discovery away from the futures market. Volatility in the futures market could drive informed trading and price discovery toward the cash market and reduce futures market information shares. The reverse would happen for increased volatility in the cash market.

The spread, trade, and volatility variables are standardized by their standard deviations to facilitate comparisons. These variables are included separately in some equations and as a ratio of one market to another in other equations. In addition, dummy variables are included in the Canadian specifications for the first three days of a contract and for contracts after the first one. ${ }^{11}$

\footnotetext{
${ }^{11}$ Day-to-day changes in price discovery were not explained by day-of-the-week effects or the presence of macro news announcements.
} 
In general, the equations fit the weakest for the futures-pit information shares for both the BrokerTec and GovPx samples. The equations for Canadian and U.S. electronic futures market shares fit much better. In the Canadian case, bid-ask spreads, the number of trades, and volatility all have a roll to play in explaining the day-to-day variability of the GG information shares. The coefficients with respect to spreads and volatility conform with expectations. Higher spreads in the futures market decrease the information share while larger spreads in the cash market raise the futures market share. The same is true for the volatility measures, although the futures market volatility is not significant. Trading in the futures market has no affect but more trading in the cash market seemed to actually have the perverse affect of increasing the futures market information share. When expressed as ratios of the futures market to the cash market, higher spread and volatility ratios significantly decreased price discovery shares. Relatively better conditions (lower volatility and spreads) on the futures market moves price discovery toward that market. Even when expressed as a ratio, trading activity had a perverse, albeit weak, affect on shares. Similar results are seen for the midpoint of the Hasbrouck bands but the fit was poorer. Two final points of interest are that there was a small shift up in futures market price discovery after the first contract and that the first three days of a new contract seemed to have significantly lower price discovery for the futures market.

In the U.S. case using BrokerTec data, the fit was much better for the electronic futures market information share than for the futures pit. For the pit, the expected effects were found for the volatility and number of trade variables but the opposite effect was found for the spread variables. The fit was much higher for the electronic futures market, where much of the explanatory power came from spreads and the number of trades. Higher spreads in the electronic futures market relative to the spot market significantly lowered the futures market share of price discovery. Relatively higher levels of trading activity in the futures market compared to the cash market raised the futures market share. The volatility variables had the correct signs but only weak effects. Greater trading on the pit market tended to raise the information share of the electronic market but this probably reflects some form of colinearity with the other variables. Recall that the trading levels for the futures market and spreads for the BrokerTec spot market declined after January 2004 and these are largely responsible for the fall in the information 
shares for the futures market over the subsequent period. There is, however, still some marginal decline in the information shares over the 2004-05 period that is unexplained.

Movements in the futures market GG information share during the GovPx sample are mostly explained by changes in trading activity. Higher futures market trading raises shares while cash market trading has the opposite effect. Hasbrouck shares are also explained by spreads although the sign does not conform with expectations.

Table 10 gives the results for the same equations as Table 9 but estimated in first difference to remove the trend component from the variables. The fit of the equations is, not surprisingly, much poorer especially for the Hasbrouck midpoint and for the GovPx and futures pit specifications. The qualitative flavour of the results is, however, quite similar. Higher spreads and volatility tend to reduce price discovery while more trading raises it.

In sum, bid-ask spreads, levels of trading activity, and volatility all have a role to play in explaining the day-to-day variation in the estimated information shares. Some of the effects are contrary to expectation and warrant further analysis. Much of the day-to-day variation in price discovery is still unexplained.

\section{Conclusions and Future Research}

This paper examines the contribution to price discovery by futures and cash markets for 10-year Government debt in both Canada and the U.S. This is an interesting question given the relatively little attention that fixed-income markets have received in the microstructure literature. Research has typically found that futures markets with their generally lower level of transaction costs dominate price discovery. Our work verifies this expectation but finds some interesting changes in the data over the sample.

About $70 \%$ of price discovery occurs on the futures market in Canada. Over the full sample since early 2002, a similar amount of price discovery occurred on the combined futures pit and 
electronic futures markets in the U.S. There has, however, been a declining degree of price discovery that has occurred on the U.S. futures markets since early 2004. Towards the end of 2005 , only just over $30 \%$ of price discovery was attributed to the electronic futures market while the futures pit still accounted for around 10\%. The declining information shares for the U.S. futures market is in part attributable to changes in the trading platform that occurred in January 2004. These changes reduced the number of trades per day on the market and, even though the overall number of contracts traded continued to increase, contributed to the decline in price discovery. The continued strong growth in spot market trading also helped to transfer price discovery to the spot market.

Future work will focus on expanding the specification of the underlying VECM to model the effects of such variables as order flow and macro news announcements. This will help us to better understand how much price discovery comes from trading in each market and how much from other factors. 


\section{References}

Baillie, R., G. Booth, Y. Tse and T. Zabotina. (2002). Price Discovery and Common Factor Models. Journal of Financial Markets 5, 309-21.

Booth, G., R. So and Y. Tse. (1999). Price Discovery in the German Equity Index Derivatives Markets. The Journal of Futures Markets 19, 619-43.

Brandt, M., K. Kavajecz, and S. Underwood. (2006). Price Discovery in the Treasury Futures Market. Unpublished manuscript.

Campbell, B., C. Chung. (2003). CGB: Poised for Takeoff, An Analysis of the Ten-Year Government of Canada Bond Futures Based on Intraday Trading Data. CIRANO working paper.

Campbell, B., C. Chung, S. Hendry. (2007). Price Discovery in Canadian Government Bond Futures and Spot. Bank of Canada Working Paper 2007-04.

Chan, K. (1992). A Further Analysis of the Lead-Lag Relationship Between the Cash Market and Stock Index Futures Market, Review of Financial Studies 5, 123-152.

Chan, K., Y. Chung and H. Johnson. (1993). Why Option Prices Lag Stock prices: A TradingBased Explanation. Journal of Finance 48, 1957-67.

D’Souza, C., C. Gaa and J. Yang. (2003). An Empirical Analysis of Liquidity and Order Flow in the Brokered Inter-dealer Market for Government of Canada Bonds. Bank of Canada Working Paper 2003-28.

Engle, R. and Kroner. (1995). Multivariate, Simultaneous Generalized ARCH. Econometric Theory 11, 122-150.

Fleming, J., B. Ostdiek and R.Whaley. (1996). Trading Costs and the Relative Rates of price Discovery in Stocks, Futures and Options Markets. Journal of Futures Markets 16, 353-87.

Garbade, K. and W. Silber. (1982). Price Movements and Price Discovery in Futures and Cash Markets. Review of Economics and Statistics 64, 289-297.

Gonzalo, J. and C. Granger. (1995). Estimation of Common Long-Memory Components in Cointegrated Systems. Journal of Business and Economic Statistics 13, 27-35.

Grossman, S. and M. Miller. (1988). Liquidity and Market Structure. Journal of Finance 43, 617-33.

Grunbichler A., F. Longstaff, and E. Schwartz. (1994). Electronic Screen Trading and the Transmission of Information: An Empirical Examination. Journal of Financial Intermediation 3, 166-187. 
Harris F., T. McInish, G. Shoesmith, and R. Wood. (1995). Cointegration, Error Correction, and Price Discovery on Informationally Linked Security Markets. Journal of Financial and Quantitative Analysis 30, 563-579.

Harris F., T. McInish, and R. Wood. (2002). Common Factor Components vs. Information Shares: Alternative Approaches to Price Discovery Research. Journal of Financial Markets 5, 277-308.

Hasbrouck, J. (1995). One Security, Many Markets: Determining the Contributions to Price Discovery. Journal of Finance 50, 1175-99.

Hasbrouck, J. (2002). Stalking the "Efficient Price" in Market Microstructure Specifications: An Overview. Journal of Financial Markets 5, 329-39.

Hasbrouck, J. (2003). Intraday Price Formation in U.S. Equity Index Markets. Journal of Finance 58, 2375-2400.

Kim, M., A. Szakmary and T. Schwarz. (1999). Trading Costs and price discovery Across Stock Index Futures and Cash Markets. Journal of Futures Markets 19, 475-98.

Lehmann, B. (2002). Some desiderata for the Measurement of Price Discovery Across Markets. Journal of Financial Markets 5, 259-276.

Martens, M. (1998). Price Discovery in Low and High Volatility Periods: Open Outcry versus Electronic Trading. Journal of International Financial Markets, Institutions and Money 8, 24360.

Mizrach, B. and C. Neely. (2005). The Microstructure of Bond Market Tatonnement, Working Paper, Rutgers University.

Poskitt, R. (1999). Price Discovery in Cash and Futures Interest Rate Markets in New Zealand, Applied Financial Economics 9, 335-364.

Stephen, J. and R. Whaley. (1990). Intraday Price Change and Trading Volume Relationships in the Stock and Stock Options Market. Journal of Finance 45, 73-94.

Stock, J. and M. Watson. (1988). Testing for Common Trends. Journal of the American Statistical Association 83, 1097-1107.

Stoll, H. and R. Whaley. (1990). The Dynamics of Stock Index and Stock Futures Returns. Journal of Financial and Quantitative Analysis 25, 441-468.

Upper, C. and T. Werner. (2002). Tail Wags Dog? Time -Varying Information Shares in the Bund Market. Discussion Paper 24/02, Economic Research Centre, Deutsche Bundesbank. 
Yan, B. and E. Zivot. (2004). The Dynamics of Price Discovery. Working Paper, Department of Economics, University of Washington.

\section{Table 1: Number of Days in Sample}

\begin{tabular}{|c|c|c|}
\hline Contract & Canada & United State \\
\hline March 2000 [1] & & 34.0 \\
\hline June 2000 [2] & & 61.0 \\
\hline September 2000 [3] & & 61.0 \\
\hline December 2000 [4] & & 56.0 \\
\hline March 2001 [5] & & 40.0 \\
\hline June 2001 [6] & & 40.0 \\
\hline \multicolumn{3}{|l|}{ September 2001 [7] } \\
\hline \multicolumn{3}{|l|}{ December 2001 [8] } \\
\hline \multicolumn{3}{|l|}{ March 2002 [9] } \\
\hline June 2002 [10] & 58.0 & 34.0 \\
\hline September 2002 [11] & 52.0 & 61.0 \\
\hline December 2002 [12] & 53.0 & 57.0 \\
\hline March 2003 [13] & 55.0 & 54.0 \\
\hline June 2003 [14] & & 60.0 \\
\hline September 2003 [15] & & 63.0 \\
\hline December 2003 [16] & & 57.0 \\
\hline March 2004 [17] & 54.0 & 54.0 \\
\hline June 2004 [18] & 58.0 & 62.0 \\
\hline September 2004 [19] & 55.0 & 59.0 \\
\hline December 2004 [20] & & 56.0 \\
\hline March 2005 [18] & & 57.0 \\
\hline June 2005 [19] & & 61.0 \\
\hline September 2005 [20] & & 64.0 \\
\hline December 2005 [21] & & 57.0 \\
\hline Sample: 10-13, 17-19 & 385.0 & \\
\hline Sample: 1 - 6 & & 292.0 \\
\hline Sample: 10 - 21 & & 856.0 \\
\hline
\end{tabular}

Note: The numbers in square brackets serve only to enumerate the contracts. 
Table 2: Mean Daily Number of Trades

\begin{tabular}{|c|c|c|c|c|c|c|}
\hline \multirow[t]{2}{*}{ Contract Maturity } & \multicolumn{2}{|c|}{ Canada } & \multicolumn{4}{|c|}{ United States } \\
\hline & CGB & CanPx & Futures - Pit & Futures - Elec & GovPx & BrokerTec \\
\hline March 2000 [1] & & & 904.1 & & 201.0 & \\
\hline June 2000 [2] & & & 937.6 & & 143.0 & \\
\hline September 2000 [3] & & & 745.0 & & 101.8 & \\
\hline December 2000 [4] & & & 724.2 & 1763.4 & 83.1 & \\
\hline March 2001 [5] & & & 971.6 & 2385.2 & 67.4 & \\
\hline June $2001[6]$ & & & 945.9 & 3610.0 & 58.1 & \\
\hline September 2001 [7] & & & 693.8 & 4856.5 & & \\
\hline December 2001 [8] & & & 1041.8 & 6804.5 & & \\
\hline March 2002 [9] & & & 1257.5 & 10694.5 & & \\
\hline June $2002[10]$ & 542.1 & 33.1 & 1080.8 & 12752.7 & & 969.2 \\
\hline September 2002 [11] & 551.4 & 32.4 & 1442.7 & 21221.4 & & 1158.4 \\
\hline December 2002 [12] & 624.0 & 36.3 & 1416.6 & 25206.1 & & 1463.9 \\
\hline March 2003 [13] & 837.1 & 32.1 & 1138.4 & 23631.1 & & 1167.4 \\
\hline June 2003 [14] & & & 1196.4 & 30183.1 & & 1395.5 \\
\hline September 2003 [15] & & & 1550.6 & 38937.8 & & 1769.5 \\
\hline December 2003 [16] & & & 1234.5 & 40952.6 & & 2248.9 \\
\hline March 2004 [17] & 744.1 & 41.9 & 1273.8 & 23559.6 & & 2368.4 \\
\hline June $2004[18]$ & 905.2 & 41.0 & 1206.5 & 16846.8 & & 3009.3 \\
\hline September 2004 [19] & 962.9 & 34.8 & 612.3 & 14003.6 & & 3039.8 \\
\hline December 2004 [20] & & & 609.7 & 17432.7 & & 4223.6 \\
\hline March 2005 [18] & & & 481.5 & 13952.7 & & 4509.9 \\
\hline June 2005 [19] & & & 489.9 & 15627.8 & & 5498.5 \\
\hline September 2005 [20] & & & 357.3 & 12192.6 & & 5702.4 \\
\hline December 2005 [21] & & & 376.0 & 13580.2 & & 7826.6 \\
\hline Full Sample & 740.2 & 36.0 & 5154.4 & 21549.5 & 108.9 & 3162.5 \\
\hline
\end{tabular}


Table 3: Mean Daily Percentage Bid-Ask Spreads

\begin{tabular}{|c|c|c|c|c|c|c|}
\hline \multirow[t]{2}{*}{ Contract Maturity } & \multicolumn{2}{|c|}{ Canada } & \multicolumn{4}{|c|}{ United States } \\
\hline & CGB & CanPx & Futures - Pit & Futures - Elec & GovPx & BrokerTec \\
\hline March 2000 [1] & & & 1.72 & & 2.70 & \\
\hline June 2000 [2] & & & 1.65 & & 2.96 & \\
\hline September 2000 [3] & & & 1.61 & & 2.63 & \\
\hline December 2000 [4] & & & 1.61 & 1.65 & 2.75 & \\
\hline March 2001 [5] & & & 1.58 & 1.68 & 4.53 & \\
\hline June 2001 [6] & & & 1.55 & 1.57 & 5.05 & \\
\hline September 2001 [7] & & & 1.51 & 1.53 & & \\
\hline December 2001 [8] & & & 1.48 & 1.51 & & \\
\hline March 2002 [9] & & & 1.51 & 1.54 & & \\
\hline June $2002[10]$ & 4.84 & 7.20 & 1.50 & 1.52 & & 4.30 \\
\hline September 2002 [11] & 4.83 & 7.55 & 1.45 & 1.46 & & 5.23 \\
\hline December 2002 [12] & 4.61 & 7.43 & 1.38 & 1.40 & & 4.93 \\
\hline March 2003 [13] & 2.94 & 6.43 & 1.38 & 1.40 & & 4.00 \\
\hline June $2003[14]$ & & & 1.36 & 1.37 & & 3.30 \\
\hline September 2003 [15] & & & 1.37 & 1.39 & & 4.41 \\
\hline December 2003 [16] & & & 1.40 & 1.42 & & 3.21 \\
\hline March 2004 [17] & 3.47 & 6.38 & 1.41 & 1.41 & & 2.48 \\
\hline June $2004[18]$ & 2.97 & 5.59 & 1.41 & 1.45 & & 2.07 \\
\hline September 2004 [19] & 2.67 & 5.65 & 1.45 & 1.47 & & 1.88 \\
\hline December 2004 [20] & & & 1.41 & 1.41 & & 1.81 \\
\hline March 2005 [21] & & & 1.42 & 1.42 & & 1.78 \\
\hline June 2005 [22] & & & 1.45 & 1.44 & & 1.83 \\
\hline September 2005 [23] & & & 1.45 & 1.41 & & 1.72 \\
\hline December 2005 [24] & & & 1.49 & 1.44 & & 1.69 \\
\hline Full Sample & 3.75 & 6.59 & 1.49 & 1.48 & 3.20 & 2.86 \\
\hline
\end{tabular}

Spreads are calculated as a percentage of the mid-point of the bid and ask prices and are expressed in basis points. The spread for the U.S. futures markets are estimated as the mean price change whenever there was a price change. All other spreads are computed directly from quote data. 
Table 4: Canadian Futures Market Price Discovery Information Shares

\begin{tabular}{|c|c|c|c|c|c|c|c|c|c|c|c|}
\hline \multirow[t]{2}{*}{ Contract Maturity } & & \multicolumn{4}{|c|}{$\begin{array}{l}\text { Information Share } \\
\text { Gonzalo-Granger }\end{array}$} & \multicolumn{3}{|c|}{\begin{tabular}{c|} 
Information Share \\
Hasbrouck LB
\end{tabular}} & \multicolumn{3}{|c|}{$\begin{array}{c}\text { Information Share } \\
\text { Hasbrouck UB }\end{array}$} \\
\hline & & Mean & Std.Dev. & \%Days $>0.5$ & \%Days $<0.5$ & Mean & Std.Dev. & \%Days $>0.5$ & Mean & Std.Dev. & \%Days $<0.5$ \\
\hline \multirow[t]{2}{*}{ June 2002 [10] } & Quotes & 0.585 & 0.155 & 0.207 & 0.103 & 0.623 & 0.204 & 0.155 & 0.720 & 0.198 & 0.034 \\
\hline & Trades & 0.525 & 0.210 & 0.086 & 0.172 & 0.651 & 0.230 & 0.121 & 0.696 & 0.226 & 0.034 \\
\hline \multirow[t]{2}{*}{ Sept. 2002 [11] } & Quotes & 0.685 & 0.155 & 0.577 & 0.000 & 0.716 & 0.176 & 0.385 & 0.818 & 0.141 & 0.000 \\
\hline & Trades & 0.555 & 0.180 & 0.077 & 0.096 & 0.689 & 0.211 & 0.173 & 0.732 & 0.207 & 0.019 \\
\hline \multirow{2}{*}{ Dec. $2002[12]$} & Quotes & 0.680 & 0.170 & 0.547 & 0.038 & 0.709 & 0.195 & 0.377 & 0.811 & 0.162 & 0.000 \\
\hline & Trades & 0.569 & 0.204 & 0.151 & 0.151 & 0.704 & 0.225 & 0.226 & 0.746 & 0.221 & 0.000 \\
\hline \multirow[t]{2}{*}{ March 2003 [13] } & Quotes & 0.703 & 0.163 & 0.455 & 0.036 & 0.722 & 0.188 & 0.345 & 0.823 & 0.154 & 0.000 \\
\hline & Trades & 0.650 & 0.227 & 0.309 & 0.073 & 0.760 & 0.261 & 0.382 & 0.790 & 0.258 & 0.000 \\
\hline \multirow[t]{2}{*}{ March 2004 [17] } & Quotes & 0.713 & 0.153 & 0.667 & 0.037 & 0.736 & 0.163 & 0.444 & 0.840 & 0.139 & 0.000 \\
\hline & Trades & 0.632 & 0.227 & 0.278 & 0.111 & 0.760 & 0.204 & 0.259 & 0.800 & 0.200 & 0.019 \\
\hline \multirow{2}{*}{ June 2004 [18] } & Quotes & 0.692 & 0.159 & 0.534 & 0.000 & 0.703 & 0.178 & 0.414 & 0.825 & 0.129 & 0.000 \\
\hline & Trades & 0.624 & 0.201 & 0.241 & 0.052 & 0.723 & 0.198 & 0.293 & 0.772 & 0.184 & 0.000 \\
\hline \multirow[t]{2}{*}{ Sept. 2004 [19] } & Quotes & 0.688 & 0.196 & 0.636 & 0.073 & 0.704 & 0.207 & 0.418 & 0.821 & 0.172 & 0.036 \\
\hline & Trades & 0.640 & 0.238 & 0.273 & 0.127 & 0.752 & 0.250 & 0.364 & 0.792 & 0.245 & 0.036 \\
\hline \multirow[t]{2}{*}{ Full Sample } & Quotes & 0.677 & 0.169 & 0.514 & 0.042 & 0.701 & 0.190 & 0.361 & 0.808 & 0.162 & 0.010 \\
\hline & Trades & 0.599 & 0.216 & 0.203 & 0.112 & 0.719 & 0.228 & 0.260 & 0.761 & 0.222 & 0.016 \\
\hline
\end{tabular}

The reported statistics are computed across the daily estimates for the contract. The columns "\%Days $>0.5$ " and "\%Days $<0.5$ " are the proportion of days for which

the $90 \%$ bootstrap confidence interval for the daily information share was above or below 0.5 , respectively. 
Table 5a: US Futures Market Price Discovery Gonzalo-Granger Information Shares

\begin{tabular}{|c|c|c|c|c|c|c|c|c|c|}
\hline \multirow[t]{2}{*}{ Contract Maturit } & & \multicolumn{4}{|c|}{$\begin{array}{c}\text { Information Share: Futures Pit } \\
\text { Gonzalo-Granger }\end{array}$} & \multicolumn{4}{|c|}{$\begin{array}{l}\text { Information Share: Electronic Futures } \\
\text { Gonzalo-Granger }\end{array}$} \\
\hline & & Mean & Std.Dev. & \%Days $>0.5$ & \%Days $<0.5$ & Mean & Std.Dev. & \%Days $>0.5$ & $\%$ Days $<0.5$ \\
\hline March 2000 [1] & GovPx - bi & 0.158 & 0.833 & 0.088 & 0.471 & - & - & - & - \\
\hline June 2000 [2] & GovPx - bi & 0.390 & 0.761 & 0.197 & 0.246 & - & - & - & - \\
\hline Sept. $2000[3]$ & GovPx - bi & 0.783 & 0.234 & 0.639 & 0.016 & - & - & - & - \\
\hline \multirow[t]{2}{*}{ Dec. $2000[4]$} & GovPx - bi & 0.653 & 0.249 & 0.286 & 0.071 & - & - & - & - \\
\hline & GovPx - tri & 0.397 & 0.203 & 0.037 & 0.463 & 0.388 & 0.259 & 0.000 & 0.389 \\
\hline \multirow[t]{2}{*}{ March 2001 [5] } & GovPx - bi & 0.880 & 0.165 & 0.825 & 0.000 & - & - & - & - \\
\hline & GovPx - tri & 0.442 & 0.157 & 0.025 & 0.200 & 0.469 & 0.202 & 0.075 & 0.200 \\
\hline \multirow[t]{2}{*}{ June 2001 [6] } & GovPx - bi & 0.856 & 0.173 & 0.575 & 0.000 & - & - & - & - \\
\hline & GovPx - tri & 0.384 & 0.163 & 0.000 & 0.375 & 0.467 & 0.175 & 0.025 & 0.175 \\
\hline Contracts 1 - 6 & GovPx - bi & 0.626 & 0.539 & 0.432 & 0.123 & - & - & - & - \\
\hline Contracts 4- 6 & GovPx - tri & 0.406 & 0.179 & 0.022 & 0.358 & 0.436 & 0.222 & 0.030 & 0.269 \\
\hline
\end{tabular}

This table reports Gonzalo-Granger information shares for the U.S. futures markets. GovPx - bi reports shares from the bivariate system of futures pit and

spot market prices while GovPx - tri reports shares for the trivariate system of futures pit, electronic futures, and spot market prices. See additional notes

Table 5b: US Futures and Spot Market Price Discovery Hasbrouck Information Shares

\begin{tabular}{|c|c|c|c|c|c|c|c|c|c|c|c|c|c|c|c|c|c|c|c|}
\hline \multirow{3}{*}{\multicolumn{2}{|c|}{ Contract Maturity }} & \multirow{2}{*}{\multicolumn{6}{|c|}{\begin{tabular}{l|l}
\multicolumn{2}{c|}{ Information Share: Futures Pit } \\
Hasbrouck LB & Hasbrouck UB
\end{tabular}}} & \multicolumn{6}{|c|}{ Information Share: Electronic Futures } & \multicolumn{6}{|c|}{ Information Share: Spot Market } \\
\hline & & & & & & & & \multicolumn{3}{|c|}{ Hasbrouck LB } & \multicolumn{3}{|c|}{ Hasbrouck UB } & \multicolumn{3}{|c|}{ Hasbrouck LB } & \multicolumn{3}{|c|}{ Hasbrouck UB } \\
\hline & & Mean & Std.Dev. & \%Days $>0.5$ & \multicolumn{3}{|c|}{\begin{tabular}{l|l|}
\multicolumn{2}{c|}{ Hasbrouck UB } \\
Mean & Std.Dev. \%Davs $<0.5$
\end{tabular}} & Mean & Std.Dev. & $\%$ Days $>0.5$ & Mean & Std.Dev. & \%Days $<0.5$ & Mean & Std.Dev. & \%Days $>0.5$ & Mean & Std.Dev. & \%Days $<0.5$ \\
\hline March $2000[1]$ & GovPx - bi & 0.235 & 0.305 & 0.059 & 0.253 & 0.313 & 0.294 & - & - & - & - & - & - & 0.747 & 0.335 & 0.294 & 0.765 & 0.329 & 0.029 \\
\hline June 2000 [2] & GovPx - bi & 0.470 & 0.373 & 0.180 & 0.520 & 0.397 & 0.197 & - & - & - & - & - & - & 0.480 & 0.396 & 0.197 & 0.530 & 0.375 & 0.164 \\
\hline Sept. $2000[3]$ & GovPx - bi & 0.853 & 0.178 & 0.754 & 0.916 & 0.150 & 0.000 & - & - & - & - & - & - & 0.084 & 0.095 & 0.000 & 0.147 & 0.143 & 0.738 \\
\hline \multirow[t]{2}{*}{ Dec. $2000[4]$} & GovPx - bi & 0.696 & 0.200 & 0.321 & 0.802 & 0.182 & 0.018 & - & - & - & - & - & - & 0.198 & 0.182 & 0.018 & 0.304 & 0.200 & 0.321 \\
\hline & GovPx - tri & 0.241 & 0.150 & 0.019 & 0.660 & 0.170 & 0.000 & 0.144 & 0.098 & 0.074 & 0.558 & 0.123 & 0.000 & 0.174 & 0.173 & 0.000 & 0.283 & 0.209 & 0.315 \\
\hline \multirow[t]{2}{*}{ March 2001 [5] } & GovPx - bi & 0.927 & 0.085 & 0.800 & 0.954 & 0.065 & 0.000 & - & - & - & - & - & - & 0.046 & 0.065 & 0.000 & 0.073 & 0.085 & 0.800 \\
\hline & GovPx - tri & 0.199 & 0.119 & 0.000 & 0.768 & 0.135 & 0.000 & 0.168 & 0.112 & 0.000 & 0.736 & 0.136 & 0.000 & 0.057 & 0.085 & 0.000 & 0.091 & 0.111 & 0.725 \\
\hline \multirow[t]{2}{*}{ June 2001 [6] } & GovPx - bi & 0.905 & 0.102 & 0.625 & 0.947 & 0.062 & 0.000 & - & - & - & - & - & - & 0.053 & 0.062 & 0.000 & 0.095 & 0.102 & 0.625 \\
\hline & GovPx - tri & 0.144 & 0.091 & 0.000 & 0.736 & 0.114 & 0.000 & 0.173 & 0.091 & 0.000 & 0.766 & 0.176 & 0.000 & 0.080 & 0.085 & 0.000 & 0.132 & 0.122 & 0.450 \\
\hline Contracts 1 - 6 & GovPx - bi & 0.688 & 0.333 & 0.459 & 0.744 & 0.338 & 0.079 & - & - & - & - & - & - & 0.256 & 0.331 & 0.079 & 0.312 & 0.327 & 0.449 \\
\hline Contracts 4- 6 & GovPx - tri & 0.200 & 0.131 & 0.007 & 0.715 & 0.151 & 0.000 & 0.160 & 0.100 & 0.030 & 0.673 & 0.177 & 0.000 & 0.111 & 0.138 & 0.000 & 0.181 & 0.181 & 0.478 \\
\hline
\end{tabular}

This table reports Hasbrouck information shares for the U.S. futures and spot markets. GovPx - bi reports shares from the bivariate system of futures pit and spot market prices while GovPX - tri reports shares for the trivariate system of futures pit, electronic futures,

and spot market prices. See additional notes with Table 4. 
Table 5c: US Futures Market Price Discovery Gonzalo Granger Information Shares

\begin{tabular}{|c|c|c|c|c|c|c|c|c|c|}
\hline \multirow[t]{2}{*}{ Contract Maturity } & & \multicolumn{4}{|c|}{$\begin{array}{c}\text { Information Share: Futures Pit } \\
\text { Gonzalo-Granger }\end{array}$} & \multicolumn{4}{|c|}{$\begin{array}{c}\text { Information Share: Electronic Futures } \\
\text { Gonzalo-Granger } \\
\end{array}$} \\
\hline & & Mean & Std.Dev. & \%Days $>0.5$ & $\%$ Days $<0.5$ & Mean & Std.Dev. & \%Days $>0.5$ & $\%$ Days $<0.5$ \\
\hline June $2002[10]$ & BrokerTec & 0.252 & 0.047 & 0.000 & 1.000 & 0.545 & 0.102 & 0.235 & 0.147 \\
\hline Sept. 2002 [11] & BrokerTec & 0.174 & 0.131 & 0.000 & 1.000 & 0.745 & 0.179 & 0.787 & 0.000 \\
\hline Dec. 2002 [12] & BrokerTec & 0.137 & 0.102 & 0.000 & 1.000 & 0.698 & 0.193 & 0.737 & 0.035 \\
\hline March 2003 [13] & BrokerTec & 0.210 & 0.139 & 0.000 & 0.963 & 0.640 & 0.177 & 0.481 & 0.037 \\
\hline June 2003 [14] & BrokerTec & 0.215 & 0.082 & 0.000 & 0.950 & 0.616 & 0.145 & 0.367 & 0.017 \\
\hline Sept. 2003 [15] & BrokerTec & 0.176 & 0.106 & 0.000 & 0.968 & 0.660 & 0.142 & 0.508 & 0.000 \\
\hline Dec. 2003 [16] & BrokerTec & 0.170 & 0.090 & 0.000 & 0.912 & 0.675 & 0.216 & 0.439 & 0.018 \\
\hline March 2004 [17] & BrokerTec & 0.155 & 0.115 & 0.000 & 0.981 & 0.589 & 0.177 & 0.296 & 0.074 \\
\hline June 2004 [18] & BrokerTec & 0.148 & 0.097 & 0.000 & 1.000 & 0.438 & 0.128 & 0.048 & 0.484 \\
\hline Sept. 2004 [19] & BrokerTec & 0.179 & 0.084 & 0.000 & 0.983 & 0.390 & 0.138 & 0.051 & 0.661 \\
\hline Dec. $2004[20]$ & BrokerTec & 0.148 & 0.094 & 0.000 & 1.000 & 0.358 & 0.100 & 0.000 & 0.679 \\
\hline March 2005 [21] & BrokerTec & 0.137 & 0.124 & 0.000 & 0.982 & 0.296 & 0.108 & 0.000 & 0.807 \\
\hline June 2005 [22] & BrokerTec & 0.134 & 0.108 & 0.000 & 0.984 & 0.342 & 0.105 & 0.000 & 0.803 \\
\hline Sept. 2005 [23] & BrokerTec & 0.114 & 0.127 & 0.000 & 0.953 & 0.304 & 0.135 & 0.016 & 0.797 \\
\hline Dec. 2005 [24] & BrokerTec & 0.126 & 0.096 & 0.000 & 1.000 & 0.304 & 0.095 & 0.000 & 0.877 \\
\hline Contracts 15 - 24 & BrokerTec & 0.162 & 0.111 & 0.000 & 0.978 & 0.505 & 0.218 & 0.264 & 0.371 \\
\hline
\end{tabular}


Table 5d: US Futures and Spot Market Price Discovery Hasbrouck Information Shares

\begin{tabular}{|c|c|c|c|c|c|c|c|c|c|c|c|c|c|c|c|c|c|c|c|}
\hline \multirow[t]{3}{*}{ Contract Maturity } & & \multicolumn{6}{|c|}{ Information Share: Futures Pit } & \multicolumn{6}{|c|}{$\begin{array}{l}\text { Information Share: Electronic Futures } \\
\end{array}$} & \multicolumn{6}{|c|}{ Information Share: Spot Market } \\
\hline & & \multicolumn{3}{|c|}{ Hasbrouck LB } & \multicolumn{3}{|c|}{ Hasbrouck UB } & \multicolumn{3}{|c|}{ Hasbrouck LB } & \multicolumn{3}{|c|}{ Hasbrouck UB } & \multicolumn{3}{|c|}{ Hasbrouck LB } & \multicolumn{3}{|c|}{ Hasbrouck UB } \\
\hline & & Mean & Std.Dev. & $\%$ Days $>0.5$ & Mean & Std.Dev. & $\%$ Days $<0.5$ & Mean & Std.Dev. & $\%$ Days $>0.5$ & Mean & Std.Dev. & $\%$ Days $<0.5$ & Mean & Std.Dev & \%Days $>0.5$ & Mean & Std.Dev. & $\%$ Days $<0.5$ \\
\hline June $2002[10]$ & BrokerTec & 0.137 & 0.058 & 0.000 & 0.263 & 0.066 & 0.971 & 0.625 & 0.110 & 0.559 & 0.768 & 0.115 & 0.000 & 0.088 & 0.092 & 0.000 & 0.124 & 0.107 & 0.912 \\
\hline Sept. 2002 [11] & BrokerTec & 0.061 & 0.046 & 0.000 & 0.172 & 0.079 & 1.000 & 0.777 & 0.109 & 0.852 & 0.898 & 0.082 & 0.000 & 0.039 & 0.061 & 0.000 & 0.057 & 0.072 & 0.967 \\
\hline Dec. 2002 [12] & BrokerTec & 0.039 & 0.032 & 0.000 & 0.135 & 0.062 & 1.000 & 0.755 & 0.142 & 0.842 & 0.877 & 0.148 & 0.018 & 0.082 & 0.150 & 0.018 & 0.117 & 0.154 & 0.912 \\
\hline March 2003 [13] & BrokerTec & 0.092 & 0.056 & 0.000 & 0.207 & 0.076 & 0.981 & 0.705 & 0.117 & 0.759 & 0.842 & 0.103 & 0.000 & 0.062 & 0.094 & 0.000 & 0.099 & 0.118 & 0.907 \\
\hline June 2003 [14] & BrokerTec & 0.079 & 0.049 & 0.000 & 0.206 & 0.067 & 0.983 & 0.684 & 0.094 & 0.517 & 0.839 & 0.084 & 0.000 & 0.077 & 0.073 & 0.000 & 0.125 & 0.094 & 0.833 \\
\hline Sept. 2003 [15] & BrokerTec & 0.053 & 0.085 & 0.000 & 0.160 & 0.089 & 0.984 & 0.724 & 0.137 & 0.683 & 0.867 & 0.126 & 0.000 & 0.077 & 0.105 & 0.000 & 0.127 & 0.135 & 0.778 \\
\hline Dec. 2003 [16] & BrokerTec & 0.038 & 0.033 & 0.000 & 0.137 & 0.059 & 1.000 & 0.715 & 0.131 & 0.649 & 0.870 & 0.109 & 0.000 & 0.088 & 0.116 & 0.000 & 0.166 & 0.157 & 0.737 \\
\hline March 2004 [17] & BrokerTec & 0.051 & 0.047 & 0.000 & 0.146 & 0.078 & 1.000 & 0.661 & 0.146 & 0.463 & 0.831 & 0.106 & 0.000 & 0.111 & 0.109 & 0.000 & 0.217 & 0.159 & 0.648 \\
\hline June 2004 [18] & BrokerTec & 0.054 & 0.049 & 0.000 & 0.136 & 0.083 & 1.000 & 0.495 & 0.166 & 0.048 & 0.685 & 0.169 & 0.016 & 0.247 & 0.188 & 0.016 & 0.403 & 0.203 & 0.290 \\
\hline Sept. 2004 [19] & BrokerTec & 0.069 & 0.049 & 0.000 & 0.140 & 0.073 & 1.000 & 0.463 & 0.177 & 0.102 & 0.644 & 0.194 & 0.000 & 0.270 & 0.173 & 0.000 & 0.433 & 0.196 & 0.271 \\
\hline Dec. 2004 [20] & BrokerTec & 0.052 & 0.044 & 0.000 & 0.122 & 0.070 & 1.000 & 0.399 & 0.142 & 0.000 & 0.610 & 0.167 & 0.036 & 0.321 & 0.184 & 0.036 & 0.517 & 0.186 & 0.071 \\
\hline March 2005 [21] & BrokerTec & 0.054 & 0.052 & 0.000 & 0.117 & 0.085 & 1.000 & 0.310 & 0.166 & 0.000 & 0.502 & 0.190 & 0.140 & 0.424 & 0.223 & 0.070 & 0.611 & 0.219 & 0.018 \\
\hline June 2005 [22] & BrokerTec & 0.043 & 0.043 & 0.000 & 0.112 & 0.069 & 1.000 & 0.331 & 0.141 & 0.000 & 0.571 & 0.161 & 0.033 & 0.368 & 0.171 & 0.000 & 0.600 & 0.180 & 0.016 \\
\hline Sept. 2005 [23] & BrokerTec & 0.035 & 0.037 & 0.000 & 0.087 & 0.064 & 1.000 & 0.302 & 0.183 & 0.016 & 0.494 & 0.197 & 0.156 & 0.453 & 0.221 & 0.063 & 0.646 & 0.220 & 0.047 \\
\hline Dec. 2005 [24] & BrokerTec & 0.036 & 0.040 & 0.000 & 0.085 & 0.062 & 1.000 & 0.292 & 0.131 & 0.000 & 0.511 & 0.161 & 0.105 & 0.436 & 0.182 & 0.070 & 0.657 & 0.162 & 0.018 \\
\hline Contracts 15 - 24 & BrokerTec & 0.057 & 0.054 & 0.000 & 0.145 & 0.084 & 0.995 & 0.546 & 0.230 & 0.357 & 0.718 & 0.210 & 0.035 & 0.214 & 0.215 & 0.019 & 0.334 & 0.278 & 0.480 \\
\hline
\end{tabular}


Table 6: US - Canadian Comparison of Price Discovery Information Shares

\begin{tabular}{|c|c|c|c|c|c|c|c|c|c|c|c|}
\hline \multirow[t]{2}{*}{ Contract Maturity } & & \multicolumn{4}{|c|}{$\begin{array}{c}\text { Information Share } \\
\text { Gonzalo-Granger }\end{array}$} & \multicolumn{3}{|c|}{$\begin{array}{c}\text { Information Share } \\
\text { Hasbrouck LB }\end{array}$} & \multicolumn{3}{|c|}{$\begin{array}{c}\text { Information Share } \\
\text { Hasbrouck UB }\end{array}$} \\
\hline & & Mean & Std.Dev. & \%Days $>0.5$ & $\%$ Days $<0.5$ & Mean & Std.Dev. & \%Days $>0.5$ & Mean & Std.Dev. & \%Days $<0.5$ \\
\hline \multirow[t]{2}{*}{ June $2002[10]$} & CDN & 0.585 & 0.155 & 0.207 & 0.103 & 0.623 & 0.204 & 0.155 & 0.720 & 0.198 & 0.034 \\
\hline & US & 0.797 & 0.114 & 0.941 & 0.000 & 0.876 & 0.107 & 0.912 & 0.912 & 0.092 & 0.000 \\
\hline \multirow[t]{2}{*}{ Sept. 2002 [11] } & CDN & 0.685 & 0.155 & 0.577 & 0.000 & 0.716 & 0.176 & 0.385 & 0.818 & 0.141 & 0.000 \\
\hline & US & 0.918 & 0.132 & 0.984 & 0.000 & 0.943 & 0.072 & 0.967 & 0.961 & 0.061 & 0.000 \\
\hline \multirow[t]{2}{*}{ Dec. 2002 [12] } & CDN & 0.680 & 0.170 & 0.547 & 0.038 & 0.709 & 0.195 & 0.377 & 0.811 & 0.162 & 0.000 \\
\hline & $\mathbf{U S}$ & 0.835 & 0.177 & 0.930 & 0.018 & 0.883 & 0.154 & 0.912 & 0.918 & 0.150 & 0.018 \\
\hline \multirow[t]{2}{*}{ March 2003 [13] } & CDN & 0.703 & 0.163 & 0.455 & 0.036 & 0.722 & 0.188 & 0.345 & 0.823 & 0.154 & 0.000 \\
\hline & US & 0.849 & 0.153 & 0.944 & 0.000 & 0.901 & 0.118 & 0.907 & 0.938 & 0.094 & 0.000 \\
\hline \multirow[t]{2}{*}{ March 2004 [17] } & CDN & 0.713 & 0.153 & 0.667 & 0.037 & 0.736 & 0.163 & 0.444 & 0.840 & 0.139 & 0.000 \\
\hline & US & 0.744 & 0.181 & 0.611 & 0.000 & 0.783 & 0.159 & 0.648 & 0.889 & 0.109 & 0.000 \\
\hline \multirow[t]{2}{*}{ June 2004 [18] } & CDN & 0.692 & 0.159 & 0.534 & 0.000 & 0.703 & 0.178 & 0.414 & 0.825 & 0.129 & 0.000 \\
\hline & $\mathbf{U S}$ & 0.586 & 0.156 & 0.306 & 0.048 & 0.597 & 0.203 & 0.290 & 0.753 & 0.188 & 0.016 \\
\hline \multirow[t]{2}{*}{ Sept. 2004 [19] } & CDN & 0.688 & 0.196 & 0.636 & 0.073 & 0.704 & 0.207 & 0.418 & 0.821 & 0.172 & 0.036 \\
\hline & $\mathbf{U S}$ & 0.550 & 0.165 & 0.271 & 0.068 & 0.548 & 0.196 & 0.271 & 0.706 & 0.173 & 0.000 \\
\hline \multirow[t]{2}{*}{ Average } & CDN & 0.677 & 0.169 & 0.514 & 0.042 & 0.701 & 0.190 & 0.361 & 0.808 & 0.162 & 0.010 \\
\hline & $\mathbf{U S}$ & 0.748 & 0.203 & 0.693 & 0.021 & 0.781 & 0.211 & 0.682 & 0.863 & 0.160 & 0.005 \\
\hline
\end{tabular}


Table 7: Cumulative Deviation from Fundamental Value

\begin{tabular}{|c|c|c|c|c|c|c|c|c|c|c|c|c|c|c|c|c|}
\hline \multirow[t]{3}{*}{ Contract Maturity } & & \multirow{2}{*}{\multicolumn{3}{|c|}{ Pit Futures Market }} & \multirow{2}{*}{\multicolumn{3}{|c|}{\begin{tabular}{|l|} 
Electronic Futures Market \\
\end{tabular}}} & \multirow{2}{*}{\multicolumn{3}{|c|}{ Spot Market }} & \multirow{2}{*}{\multicolumn{3}{|c|}{ Spot less Elec. Futures }} & \multirow{2}{*}{\multicolumn{3}{|c|}{$\%$ of Days of significant difference }} \\
\hline & & & & & & & & & & & & & & & & \\
\hline & & $5 \%$ & Mean & $95 \%$ & $5 \%$ & Mean & $95 \%$ & $5 \%$ & Mean & $95 \%$ & $5 \%$ & Mean & $95 \%$ & Spot>Futures & Futures $>$ Spot & No Difference \\
\hline \multirow[t]{2}{*}{ June $2002[10]$} & CDN & & & & 0.035 & 0.036 & 0.042 & 0.049 & 0.057 & 0.059 & 0.009 & 0.021 & 0.022 & 0.224 & 0.103 & 0.672 \\
\hline & US & 0.023 & 0.024 & 0.032 & 0.018 & 0.019 & 0.025 & 0.067 & 0.076 & 0.080 & 0.045 & 0.057 & 0.059 & 0.912 & 0.029 & 0.059 \\
\hline \multirow[t]{2}{*}{ Sept. 2002 [11] } & CDN & & & & 0.029 & 0.031 & 0.037 & 0.061 & 0.073 & 0.083 & 0.028 & 0.042 & 0.051 & 0.462 & 0.000 & 0.538 \\
\hline & us & 0.049 & 0.058 & 0.071 & 0.027 & 0.031 & 0.044 & 0.130 & 0.151 & 0.160 & 0.097 & 0.120 & 0.123 & 0.918 & 0.000 & 0.082 \\
\hline \multirow[t]{2}{*}{ Dec. 2002 [12] } & CDN & & & & 0.028 & 0.029 & 0.035 & 0.055 & 0.069 & 0.074 & 0.022 & 0.040 & 0.044 & 0.396 & 0.038 & 0.566 \\
\hline & us & 0.065 & 0.073 & 0.085 & 0.042 & 0.046 & 0.059 & 0.126 & 0.145 & 0.154 & 0.076 & 0.099 & 0.102 & 0.789 & 0.018 & 0.193 \\
\hline \multirow{2}{*}{ March 2003 [13] } & CDN & & & & 0.024 & 0.023 & 0.030 & 0.051 & 0.063 & 0.065 & 0.023 & 0.040 & 0.038 & 0.382 & 0.018 & 0.600 \\
\hline & US & 0.060 & 0.080 & 0.100 & 0.031 & 0.039 & 0.059 & 0.099 & 0.114 & 0.129 & 0.060 & 0.075 & 0.078 & 0.833 & 0.000 & 0.167 \\
\hline \multirow[t]{2}{*}{ June 2003 [10] } & CDN & & & & & & & & & & & & & & & \\
\hline & US & 0.060 & 0.082 & 0.101 & 0.040 & 0.044 & 0.065 & 0.115 & 0.145 & 0.158 & 0.064 & 0.102 & 0.105 & 0.750 & 0.000 & 0.250 \\
\hline \multirow[t]{2}{*}{ Sept. 2003 [11] } & CDN & & & & & & & & & & & & & & & \\
\hline & US & 0.068 & 0.070 & 0.104 & 0.064 & 0.070 & 0.102 & 0.159 & 0.198 & 0.211 & 0.068 & 0.128 & 0.137 & 0.619 & 0.016 & 0.365 \\
\hline \multirow[t]{2}{*}{ Dec. 2003 [12] } & CDN & & & & & & & & & & & & & & & \\
\hline & Us & 0.076 & 0.095 & 0.113 & 0.063 & 0.082 & 0.100 & 0.137 & 0.181 & 0.193 & 0.063 & 0.098 & 0.103 & 0.579 & 0.018 & 0.404 \\
\hline \multirow[t]{2}{*}{ March 2004 [17] } & CDN & & & & 0.020 & 0.020 & 0.024 & 0.044 & 0.048 & 0.050 & 0.021 & 0.028 & 0.029 & 0.426 & 0.037 & 0.537 \\
\hline & US & 0.046 & 0.049 & 0.069 & 0.038 & 0.041 & 0.062 & 0.089 & 0.116 & 0.127 & 0.041 & 0.075 & 0.074 & 0.500 & 0.000 & 0.500 \\
\hline \multirow[t]{2}{*}{ June 2004 [18] } & CDN & & & & 0.023 & 0.024 & 0.029 & 0.046 & 0.052 & 0.055 & 0.020 & 0.028 & 0.029 & 0.414 & 0.017 & 0.569 \\
\hline & US & 0.059 & 0.063 & 0.073 & 0.050 & 0.054 & 0.064 & 0.055 & 0.063 & 0.072 & -0.005 & 0.009 & 0.017 & 0.194 & 0.113 & 0.694 \\
\hline \multirow[t]{2}{*}{ Sept. 2004 [19] } & CDN & & & & 0.021 & 0.021 & 0.025 & 0.037 & 0.042 & 0.047 & 0.014 & 0.022 & 0.024 & 0.473 & 0.055 & 0.473 \\
\hline & US & 0.040 & 0.043 & 0.051 & 0.031 & 0.035 & 0.042 & 0.045 & 0.058 & 0.062 & 0.009 & 0.023 & 0.024 & 0.271 & 0.051 & 0.678 \\
\hline \multirow[t]{2}{*}{ Dec. 2004 [12] } & CDN & & & & & & & & & & & & & & & \\
\hline & US & 0.045 & 0.049 & 0.061 & 0.036 & 0.040 & 0.052 & 0.039 & 0.048 & 0.057 & -0.005 & 0.009 & 0.013 & 0.143 & 0.071 & 0.786 \\
\hline \multirow[t]{2}{*}{ March 2005 [13] } & CDN & & & & & & & & & & & & & & & \\
\hline & US & 0.080 & 0.089 & 0.114 & 0.068 & 0.077 & 0.102 & 0.059 & 0.076 & 0.099 & -0.027 & -0.001 & 0.015 & 0.053 & 0.158 & 0.789 \\
\hline \multirow[t]{2}{*}{ June $2005[10]$} & CDN & & & & & & & & & & & & & & & \\
\hline & US & 0.064 & 0.067 & 0.088 & 0.056 & 0.059 & 0.080 & 0.053 & 0.064 & 0.085 & -0.019 & 0.006 & 0.020 & 0.066 & 0.148 & 0.787 \\
\hline \multirow[t]{2}{*}{ Sept. 2005 [11] } & CDN & & & & & & & & & & & & & & & \\
\hline & US & 0.089 & 0.109 & 0.127 & 0.078 & 0.098 & 0.116 & 0.062 & 0.081 & 0.103 & -0.030 & -0.018 & -0.001 & 0.078 & 0.172 & 0.750 \\
\hline \multirow[t]{2}{*}{ Dec. 2005 [12] } & CDN & & & & & & & & & & & & & & & \\
\hline & US & 0.062 & 0.070 & 0.084 & 0.050 & 0.058 & 0.073 & 0.044 & 0.057 & 0.065 & -0.020 & -0.001 & 0.006 & 0.035 & 0.070 & 0.895 \\
\hline \multirow[t]{3}{*}{ Average } & CDN & & & & 0.028 & 0.026 & 0.030 & 0.052 & 0.058 & 0.057 & 0.023 & 0.031 & 0.029 & 0.395 & 0.039 & 0.566 \\
\hline & dn sample & 0.055 & 0.058 & 0.064 & 0.039 & 0.039 & 0.046 & 0.094 & 0.104 & 0.105 & 0.052 & 0.065 & 0.061 & 0.609 & 0.031 & 0.360 \\
\hline & ull sample & 0.068 & 0.070 & 0.076 & 0.055 & 0.054 & 0.062 & 0.096 & 0.106 & 0.105 & 0.038 & 0.052 & 0.047 & 0.433 & 0.060 & 0.507 \\
\hline US: Gr & Px sample & 0.099 & 0.293 & 0.146 & & & & 0.158 & 0.508 & 0.242 & & & & & & \\
\hline
\end{tabular}


Table 8: Number of Minutes until Long-Run Equilibrium is Attained

\begin{tabular}{|c|c|c|c|c|c|c|c|c|c|c|c|c|c|c|c|c|}
\hline \multirow[t]{3}{*}{ Contract Maturity } & & \multirow{2}{*}{\multicolumn{3}{|c|}{ Pit Futures Market }} & \multirow{2}{*}{\multicolumn{3}{|c|}{\begin{tabular}{|l|} 
Electronic Futures Market \\
\end{tabular}}} & \multirow{2}{*}{\multicolumn{3}{|c|}{ Spot Market }} & \multicolumn{3}{|c|}{ Spot less Elec. Futures } & \multirow{2}{*}{\multicolumn{3}{|c|}{ \% of Days of significant difference }} \\
\hline & & & & & & & & & & & & & & & & \\
\hline & & $5 \%$ & Mean & $95 \%$ & $5 \%$ & Mean & $95 \%$ & $5 \%$ & Mean & $95 \%$ & $5 \%$ & Mean & $95 \%$ & Spot>Futures & Futures $>$ Spot & No Difference \\
\hline \multirow[t]{2}{*}{ June $2002[10]$} & CDN & & & & 7.689 & 8.200 & 8.995 & 8.900 & 10.402 & 10.097 & 0.294 & 2.202 & 2.020 & 0.224 & 0.121 & 0.655 \\
\hline & US & 2.179 & 2.232 & 2.936 & 1.896 & 1.957 & 2.540 & 5.466 & 6.109 & 6.327 & 3.194 & 4.152 & 4.161 & 0.912 & 0.029 & 0.059 \\
\hline \multirow[t]{2}{*}{ Sept. 2002 [11] } & CDN & & & & 6.013 & 6.413 & 7.523 & 8.654 & 10.028 & 10.105 & 1.641 & 3.615 & 3.606 & 0.365 & 0.000 & 0.635 \\
\hline & US & 3.545 & 3.801 & 4.456 & 2.752 & 2.968 & 3.693 & 7.384 & 8.232 & 8.450 & 4.083 & 5.264 & 5.300 & 0.869 & 0.000 & 0.131 \\
\hline \multirow{2}{*}{ Dec. 2002 [12] } & CDN & & & & 5.900 & 6.349 & 7.920 & 8.045 & 9.951 & 9.797 & 0.722 & 3.602 & 3.435 & 0.340 & 0.057 & 0.604 \\
\hline & US & 5.006 & 5.626 & 6.298 & 4.241 & 4.470 & 5.604 & 7.432 & 8.468 & 8.760 & 2.256 & 3.998 & 4.078 & 0.702 & 0.035 & 0.263 \\
\hline \multirow[t]{2}{*}{ March 2003 [13] } & CDN & & & & 6.342 & 6.148 & 8.612 & 9.722 & 12.023 & 11.621 & 1.761 & 5.875 & 4.751 & 0.273 & 0.036 & 0.691 \\
\hline & US & 3.677 & 3.994 & 4.919 & 2.836 & 2.918 & 3.941 & 7.195 & 8.074 & 8.353 & 3.795 & 5.156 & 4.989 & 0.796 & 0.000 & 0.204 \\
\hline \multirow[t]{2}{*}{ June 2003 [10] } & CDN & & & & & & & & & & & & & & & \\
\hline & US & 4.568 & 5.215 & 6.263 & 3.690 & 4.066 & 5.378 & 8.189 & 10.276 & 10.076 & 3.305 & 6.209 & 5.867 & 0.717 & 0.000 & 0.283 \\
\hline \multirow[t]{2}{*}{ Sept. 2003 [11] } & CDN & & & & & & & & & & & & & & & \\
\hline & US & 4.719 & 5.102 & 6.419 & 4.503 & 4.844 & 6.399 & 8.838 & 11.030 & 10.788 & 2.955 & 6.185 & 5.757 & 0.571 & 0.032 & 0.397 \\
\hline \multirow[t]{2}{*}{ Dec. 2003 [12] } & CDN & & & & & & & & & & & & & & & \\
\hline & US & 5.370 & 6.920 & 7.215 & 5.314 & 7.405 & 7.411 & 9.116 & 11.835 & 11.147 & 2.516 & 4.430 & 5.075 & 0.526 & 0.018 & 0.456 \\
\hline \multirow[t]{2}{*}{ March 2004 [17] } & CDN & & & & 4.596 & 4.716 & 5.537 & 7.001 & 7.725 & 7.791 & 1.754 & 3.009 & 2.917 & 0.370 & 0.037 & 0.593 \\
\hline & US & 3.486 & 3.952 & 4.951 & 3.277 & 3.760 & 5.062 & 6.544 & 8.436 & 8.296 & 2.073 & 4.676 & 4.413 & 0.500 & 0.000 & 0.500 \\
\hline \multirow{2}{*}{ June 2004 [18] } & CDN & & & & 5.563 & 5.810 & 6.651 & 7.943 & 8.991 & 8.939 & 1.615 & 3.181 & 3.062 & 0.310 & 0.017 & 0.672 \\
\hline & US & 4.725 & 5.268 & 6.155 & 4.477 & 5.064 & 6.079 & 4.966 & 5.943 & 6.341 & -0.686 & 0.879 & 1.446 & 0.242 & 0.161 & 0.597 \\
\hline \multirow[t]{2}{*}{ Sept. 2004 [19] } & CDN & & & & 5.010 & 5.301 & 6.324 & 7.422 & 8.545 & 8.684 & 1.553 & 3.244 & 3.277 & 0.382 & 0.055 & 0.564 \\
\hline & US & 3.601 & 3.989 & 4.676 & 2.966 & 3.267 & 4.248 & 4.595 & 5.877 & 5.792 & 0.806 & 2.609 & 2.374 & 0.322 & 0.034 & 0.644 \\
\hline \multirow[t]{2}{*}{ Dec. 2004 [12] } & CDN & & & & & & & & & & & & & & & \\
\hline & US & 3.982 & 4.316 & 5.058 & 3.618 & 3.776 & 4.927 & 3.961 & 5.085 & 5.144 & -0.631 & 1.310 & 1.185 & 0.232 & 0.071 & 0.696 \\
\hline \multirow[t]{2}{*}{ March 2005 [13] } & CDN & & & & & & & & & & & & & & & \\
\hline & US & 7.937 & 7.963 & 10.584 & 7.597 & 8.493 & 10.583 & 6.721 & 8.331 & 9.292 & -3.081 & -0.162 & 0.928 & 0.140 & 0.123 & 0.737 \\
\hline \multirow[t]{2}{*}{ June 2005 [10] } & CDN & & & & & & & & & & & & & & & \\
\hline & US & 6.244 & 6.569 & 8.715 & 5.913 & 6.309 & 8.670 & 6.074 & 7.662 & 8.266 & -1.983 & 1.353 & 1.726 & 0.197 & 0.066 & 0.738 \\
\hline \multirow[t]{2}{*}{ Sept. 2005 [11] } & CDN & & & & & & & & & & & & & & & \\
\hline & US & 9.436 & 11.375 & 12.023 & 9.255 & 11.180 & 12.227 & 7.824 & 9.185 & 10.148 & -3.494 & -1.995 & -0.013 & 0.141 & 0.078 & 0.781 \\
\hline \multirow[t]{2}{*}{ Dec. 2005 [12] } & CDN & & & & & & & & & & & & & & & \\
\hline & US & 6.356 & 7.224 & 8.217 & 5.693 & 6.378 & 7.899 & 5.785 & 7.573 & 7.532 & -1.597 & 1.195 & 1.304 & 0.140 & 0.053 & 0.807 \\
\hline \multirow[t]{4}{*}{ Average } & CDN & & & & 6.317 & 6.148 & 6.914 & 8.639 & 9.668 & 9.162 & 1.900 & 3.520 & 2.684 & 0.322 & 0.047 & 0.631 \\
\hline & dn sample & 4.194 & 4.251 & 4.665 & 3.658 & 3.595 & 4.175 & 6.598 & 7.347 & 7.094 & 2.598 & 3.752 & 3.260 & 0.598 & 0.039 & 0.362 \\
\hline & full sample & 5.669 & 5.706 & 6.126 & 5.270 & 5.258 & 5.783 & 7.308 & 8.215 & 7.761 & 1.673 & 2.957 & 2.343 & 0.452 & 0.048 & 0.500 \\
\hline & Px sample & 23.196 & 52.4387 & 29.643 & & & & 17.377 & 33.6961 & 21.335 & & & & & & \\
\hline
\end{tabular}


Table 9: Regression Results using Futures Market Daily Information Shares

\begin{tabular}{|c|c|c|c|c|c|c|c|c|c|c|c|c|c|c|c|c|}
\hline & CDN & CDN & Btec - Pit & $\begin{array}{r}\text { Gonzalo- } \\
\text { Btec - Pit }\end{array}$ & $\begin{array}{l}\text { o-Granger } \\
\text { Btec - Elec } \\
\end{array}$ & Btec - Elec & GovPx & GovPx & CDN & CDN & Btec - Pit & $\begin{array}{l}\text { Hasbrouck } \\
\text { Btec - Pit }\end{array}$ & $\begin{array}{l}\text { Midpoint } \\
\text { Btec - Elec }\end{array}$ & Btec - Elec & GovPx & GovPx \\
\hline Constant & $\begin{array}{c}0.486 \\
(7.731)^{* * *}\end{array}$ & $\begin{array}{c}1.217 \\
(11.763)^{* * *}\end{array}$ & $\begin{array}{c}0.186 \\
(2.147)^{* *}\end{array}$ & $\begin{array}{l}0.016 \\
(0.222)\end{array}$ & $\begin{array}{c}0.412 \\
(3.569)^{* * * *}\end{array}$ & $\begin{array}{c}1.695 \\
(7.676)^{* * *}\end{array}$ & $\begin{array}{c}1.922 \\
(2.952)^{* * *}\end{array}$ & $\begin{array}{l}-1.813 \\
(-1.453)\end{array}$ & $\begin{array}{c}0.585 \\
(8.565)^{* * * *}\end{array}$ & $\begin{array}{c}1.113 \\
(9.866)^{* * *}\end{array}$ & $\begin{array}{c}0.093 \\
(1.811)^{*}\end{array}$ & $\begin{array}{c}-0.060 \\
(-1.473)\end{array}$ & $\begin{array}{c}0.529 \\
(4.314)^{* * * *}\end{array}$ & $\begin{array}{c}0.609 \\
(2.798)^{* * * *}\end{array}$ & $\begin{array}{c}1.959 \\
(5.658)^{* * * *}\end{array}$ & $\begin{array}{c}-2.290 \\
(-3.331)^{* * *}\end{array}$ \\
\hline FIRST DAYS ${ }^{5}$ & $\begin{array}{c}-0.150 \\
(-3.627)^{* * * *}\end{array}$ & $\begin{array}{c}-0.146 \\
(-3.574)^{* * *}\end{array}$ & & & & & & & \begin{tabular}{|c}
-0.164 \\
$(-3.643)^{* * * *}$
\end{tabular} & $\begin{array}{c}-0.159 \\
(-3.576)^{* * *}\end{array}$ & & & & & & \\
\hline CONTRACT \#11-\#19 & $\begin{array}{c}0.060 \\
(2.575)^{* *}\end{array}$ & $\begin{array}{c}0.056 \\
(2.538)^{* *}\end{array}$ & & & & & & & $\begin{array}{c}0.066 \\
(2.611)^{* * * *}\end{array}$ & $\begin{array}{c}0.060 \\
(2.500)^{* *}\end{array}$ & & & & & & \\
\hline PIT SPREAD & & & $\begin{array}{c}0.003 \\
(0.771)\end{array}$ & & $\begin{array}{l}0.005 \\
(1.092)\end{array}$ & & $\begin{array}{c}-0.062 \\
(-1.722)^{*}\end{array}$ & & & & $\begin{array}{r}0.001 \\
(0.627)\end{array}$ & & $\begin{array}{c}0.003 \\
(0.562)\end{array}$ & & $\begin{array}{c}-0.054 \\
(-2.777)^{* * *}\end{array}$ & \\
\hline E. FUTURES SPREAD & $\begin{array}{c}-0.051 \\
(-4.090)^{* * *}\end{array}$ & & $\begin{array}{l}0.002 \\
(0.526)\end{array}$ & & $\begin{array}{c}-0.010 \\
(-1.730)^{*}\end{array}$ & & & & $\begin{array}{l}-0.037 \\
(-2.676)^{* * *}\end{array}$ & & $\begin{array}{r}0.003 \\
(1.323)\end{array}$ & & $\begin{array}{l}-0.005 \\
(-0.850)\end{array}$ & & & \\
\hline CASH SPREAD & $\begin{array}{c}0.038 \\
(3.699)^{* * *}\end{array}$ & & $\begin{array}{c}-0.006 \\
(-1.087)\end{array}$ & & $\begin{array}{c}0.070 \\
(9.735)^{* * *}\end{array}$ & & $\begin{array}{c}-0.047 \\
(-0.998)\end{array}$ & & $\begin{array}{c}0.030 \\
(2.731)^{* * * *}\end{array}$ & & $\begin{array}{c}-0.004 \\
(-1.155)\end{array}$ & & $\begin{array}{c}0.043 \\
(5.582)^{* * * *}\end{array}$ & & $\begin{array}{c}-0.042 \\
(-1.679) *\end{array}$ & \\
\hline PIT/E. FUTURES SPREAD RATIO & & & & $\begin{array}{r}-0.030 \\
(-0.138)\end{array}$ & & $\begin{array}{c}0.079 \\
(0.284)\end{array}$ & & & & & & $\begin{array}{c}-0.034 \\
(-0.273)\end{array}$ & & $\begin{array}{c}0.023 \\
(0.083)\end{array}$ & & \\
\hline FUTURES/CASH SPREAD RATIO & & $\begin{array}{c}-0.629 \\
(-3.758)^{* * *}\end{array}$ & & $\begin{array}{c}0.312 \\
(4.649)^{* * *}\end{array}$ & & $\begin{array}{c}-1.694 \\
(-8.193)^{* * *}\end{array}$ & & $\begin{array}{c}1.362 \\
(1.089)\end{array}$ & & $\begin{array}{c}-0.448 \\
(-2.454)^{* *}\end{array}$ & & $\begin{array}{c}0.202 \\
(5.184)^{* * * *}\end{array}$ & & $\begin{array}{c}-0.484 \\
(-2.374)^{* *}\end{array}$ & & $\begin{array}{c}2.062 \\
(2.992)^{* * *}\end{array}$ \\
\hline \# OF TRADES - PIT & & & $\begin{array}{c}0.000 \\
(-0.050)\end{array}$ & & $\begin{array}{c}0.038 \\
(4.299)^{* * *}\end{array}$ & & $\begin{array}{c}0.141 \\
(3.145)^{* * *}\end{array}$ & & & & $\begin{array}{c}0.002 \\
(0.581)\end{array}$ & & $\begin{array}{c}0.048 \\
(5.174)^{* * * *}\end{array}$ & & $\begin{array}{c}0.085 \\
(3.585)^{* * *}\end{array}$ & \\
\hline \# OF TRADES - E. FUTURES & $\begin{array}{l}0.006 \\
(0.561)\end{array}$ & & $\begin{array}{c}0.003 \\
(0.572)\end{array}$ & & $\begin{array}{c}0.049 \\
(6.594) * * *\end{array}$ & & & & $\begin{array}{r}0.006 \\
(0.506)\end{array}$ & & $\begin{array}{c}-0.007 \\
(-2.178)^{* *}\end{array}$ & & $\begin{array}{c}0.053 \\
(6.608)^{* * *}\end{array}$ & & & \\
\hline \# OF TRADES - CASH & $\begin{array}{c}0.036 \\
(3.758)^{* * *}\end{array}$ & & $\begin{array}{c}-0.033 \\
(-7.247) * * *\end{array}$ & & $\begin{array}{c}-0.032 \\
(-5.191)^{* * * *}\end{array}$ & & $\begin{array}{c}-0.218 \\
(-5.221)^{* * *}\end{array}$ & & $\begin{array}{c}0.026 \\
(2.513)^{* *}\end{array}$ & & $\begin{array}{c}-0.028 \\
(-10.300)^{* * *}\end{array}$ & & $\begin{array}{c}-0.057 \\
(-8.719)^{* * *}\end{array}$ & & $\begin{array}{c}-0.196 \\
(-8.860)^{* * *}\end{array}$ & \\
\hline PIT/E. FUTURES TRADE RATIO & & & & $\begin{array}{l}0.016 \\
(0.300)\end{array}$ & & $\begin{array}{c}-0.018 \\
(-0.304)\end{array}$ & & & & & & $\begin{array}{c}0.074 \\
(2.391)^{* *}\end{array}$ & & $\begin{array}{c}0.133 \\
(2.275)^{* *}\end{array}$ & & \\
\hline FUTURES/CASH TRADE RATIO & & $\begin{array}{c}-0.168 \\
(-1.914)^{*}\end{array}$ & & $\begin{array}{c}0.200 \\
(6.005) * * *\end{array}$ & & $\begin{array}{c}0.518 \\
(13.729)^{* * *}\end{array}$ & & $\begin{array}{c}1.998 \\
(5.214)^{* * *}\end{array}$ & & $\begin{array}{c}-0.095 \\
(-0.995)\end{array}$ & & $\begin{array}{c}0.145 \\
(7.477)^{* * * *}\end{array}$ & & $\begin{array}{c}0.700 \\
(18.820)^{* * * *}\end{array}$ & & $\begin{array}{c}1.912 \\
(9.056)^{* * *}\end{array}$ \\
\hline PIT FUTURES VOLATILITY & & & $\begin{array}{c}-0.043 \\
(-3.765)^{* * *}\end{array}$ & & $\begin{array}{c}0.056 \\
(3.739)^{* * *}\end{array}$ & & $\begin{array}{l}0.003 \\
(0.096)\end{array}$ & & & & $\begin{array}{c}-0.022 \\
(-3.256)^{* * *}\end{array}$ & & $\begin{array}{c}0.046 \\
(2.885)^{* * *}\end{array}$ & & $\begin{array}{c}-0.004 \\
(-0.204)\end{array}$ & \\
\hline E. FUTURES VOLATILITY & $\begin{array}{r}-0.023 \\
(-1.514)\end{array}$ & & $\begin{array}{c}-0.007 \\
(-0.586)\end{array}$ & & $\begin{array}{c}-0.024 \\
(-1.397)\end{array}$ & & & & $\begin{array}{c}-0.013 \\
(-0.817)\end{array}$ & & $\begin{array}{r}0.002 \\
(0.331)\end{array}$ & & $\begin{array}{c}-0.021 \\
(-1.143)\end{array}$ & & & \\
\hline CASH VOLATILITY & $\begin{array}{c}0.045 \\
(2.766)^{* * *}\end{array}$ & & $\begin{array}{c}0.018 \\
(1.728)^{*}\end{array}$ & & $\begin{array}{c}-0.001 \\
(-0.058)\end{array}$ & & $\begin{array}{c}-0.006 \\
(-0.145)\end{array}$ & & $\begin{array}{c}0.023 \\
(1.293)\end{array}$ & & $\begin{array}{r}0.009 \\
(1.464)\end{array}$ & & $\begin{array}{c}-0.018 \\
(-1.218)\end{array}$ & & $\begin{array}{c}-0.007 \\
(-0.327)\end{array}$ & \\
\hline PIT/E. FUTURES VOLATILITY RATI & & & & $\begin{array}{c}-0.177 \\
(-1.746)^{*}\end{array}$ & & $\begin{array}{c}0.228 \\
(1.696)^{*}\end{array}$ & & & & & & $\begin{array}{c}-0.093 \\
(-1.584)\end{array}$ & & $\begin{array}{c}0.095 \\
(0.717)\end{array}$ & & \\
\hline FUTURES/CASH VOL. RATIO & & $\begin{array}{c}-0.555 \\
(-6.998)^{* * *}\end{array}$ & & $\begin{array}{c}-0.150 \\
(-1.880)^{*}\end{array}$ & & $\begin{array}{c}-0.121 \\
(-1.153)\end{array}$ & & $\begin{array}{c}0.091 \\
(0.373)\end{array}$ & & $\begin{array}{c}-0.398 \\
(-4.603)^{* * * *}\end{array}$ & & $\begin{array}{c}-0.061 \\
(-1.317)\end{array}$ & & $\begin{array}{c}-0.122 \\
(-1.181)\end{array}$ & & $\begin{array}{c}0.128 \\
(0.948)\end{array}$ \\
\hline RSQ & 0.219 & 0.245 & 0.145 & 0.068 & 0.611 & 0.579 & 0.166 & 0.146 & 0.127 & 0.151 & 0.173 & 0.146 & 0.563 & 0.594 & 0.367 & 0.303 \\
\hline \#obs & 385 & 385 & 875 & 875 & 875 & 875 & 292 & 292 & 385 & 385 & 875 & 875 & 875 & 875 & 292 & 292 \\
\hline
\end{tabular}


Table 10: Regression Results using Futures Market Daily Information Shares: First Differences

\begin{tabular}{|c|c|c|c|c|c|c|c|c|c|c|c|c|c|c|c|c|}
\hline & CDN & CDN & Btec - Pit & $\begin{array}{r}\text { Gonzalo- } \\
\text { Btec - Pit }\end{array}$ & $\begin{array}{l}\text {-Granger } \\
\text { Btec -Elec }\end{array}$ & Btec - Elec & GovPx & GovPx & CDN & CDN & Btec - Pit & $\begin{array}{l}\text { Hasbrouck } \\
\text { Btec - Pit }\end{array}$ & \begin{tabular}{|l|} 
k Midpoint \\
Btec - Elec
\end{tabular} & Btec-Elec & GovPx & GovPx \\
\hline Constant & $\begin{array}{c}0.000 \\
(-0.013)\end{array}$ & $\begin{array}{c}0.000 \\
(0.032)\end{array}$ & $\begin{array}{c}0.000 \\
(-0.035)\end{array}$ & $\begin{array}{c}0.000 \\
(-0.037)\end{array}$ & $\begin{array}{c}-0.001 \\
(-0.097)\end{array}$ & $\begin{array}{c}-0.024 \\
(-0.003)\end{array}$ & $\begin{array}{c}0.000 \\
(0.013)\end{array}$ & $\begin{array}{c}0.000 \\
(-0.008)\end{array}$ & $\begin{array}{c}0.000 \\
(0.019)\end{array}$ & $\begin{array}{c}0.001 \\
(0.050)\end{array}$ & $\begin{array}{c}0.000 \\
(-0.094)\end{array}$ & $\begin{array}{c}0.000 \\
(-0.072)\end{array}$ & $\begin{array}{c}-0.001 \\
(-0.094)\end{array}$ & $\begin{array}{c}0.000 \\
(0.013)\end{array}$ & $\begin{array}{c}0.000 \\
(-0.002)\end{array}$ & $\begin{array}{c}0.000 \\
(-0.023)\end{array}$ \\
\hline FIRST DAYS $^{5}$ & $\begin{array}{c}-0.117 \\
(-1.841)^{*}\end{array}$ & $\begin{array}{c}-0.113 \\
(-1.836)^{*}\end{array}$ & & & & & & & $\begin{array}{c}-0.127 \\
(-1.820)^{*}\end{array}$ & $\begin{array}{c}-0.122 \\
(-1.803)^{*}\end{array}$ & & & & & & \\
\hline CONTRACT \#2-\#7 & $\begin{array}{c}0.336 \\
(1.481)\end{array}$ & $\begin{array}{c}0.246 \\
(1.115)\end{array}$ & & & & & & & $\begin{array}{c}0.369 \\
(1.481)\end{array}$ & $\begin{array}{c}0.294 \\
(1.206)\end{array}$ & & & & & & \\
\hline PIT SPREAD & & & $\begin{array}{c}0.003 \\
(0.843)\end{array}$ & & $\begin{array}{c}0.002 \\
(0.371)\end{array}$ & & $\begin{array}{c}0.001 \\
(0.030)\end{array}$ & & & & $\begin{array}{c}0.002 \\
(1.020)\end{array}$ & & $\begin{array}{c}-0.002 \\
(-0.398)\end{array}$ & & $\begin{array}{l}0.007 \\
(0.481)\end{array}$ & \\
\hline E. FUTURES SPREAD & $\begin{array}{c}-0.064 \\
(-4.070)^{* * *}\end{array}$ & & $\begin{array}{c}-0.002 \\
(-0.375)\end{array}$ & & $\begin{array}{c}-0.016 \\
(-2.320)^{* *}\end{array}$ & & & & $\begin{array}{c}-0.045 \\
(-2.607)^{* * *}\end{array}$ & & $\begin{array}{c}-0.001 \\
(-0.307)\end{array}$ & & $\begin{array}{c}-0.005 \\
(-0.736)\end{array}$ & & & \\
\hline CASH SPREAD & $\begin{array}{c}0.035 \\
(3.035)^{* * *}\end{array}$ & & $\begin{array}{c}-0.009 \\
(-0.812)\end{array}$ & & $\begin{array}{c}0.041 \\
(2.933)^{* * *}\end{array}$ & & $\begin{array}{l}-0.046 \\
(-0.695)\end{array}$ & & $\begin{array}{c}0.028 \\
(2.235)^{* *}\end{array}$ & & $\begin{array}{c}-0.007 \\
(-1.182)\end{array}$ & & $\begin{array}{l}0.005 \\
(0.377)\end{array}$ & & $\begin{array}{c}0.008 \\
(0.286)\end{array}$ & \\
\hline PIT/E. FUTURES SPREAD RATIO & & & & $\begin{array}{c}-0.240 \\
(-1.030)\end{array}$ & & $\begin{array}{c}0.032 \\
(0.118)\end{array}$ & & & & & & $\begin{array}{c}-0.141 \\
(-1.100)\end{array}$ & & $\begin{array}{c}-0.105 \\
(-0.385)\end{array}$ & & \\
\hline FUTURES/CASH SPREAD RATIO & & $\begin{array}{c}-0.552 \\
(-3.000)^{* * * *}\end{array}$ & & $\begin{array}{c}0.542 \\
(3.921)^{* * * *}\end{array}$ & & $\begin{array}{c}-2.423 \\
(-6.173)^{* * *}\end{array}$ & & $\begin{array}{l}1.629 \\
(0.943)\end{array}$ & & $\begin{array}{c}-0.421 \\
(-2.076)^{* *}\end{array}$ & & $\begin{array}{c}0.356 \\
(4.692)^{* * *}\end{array}$ & & $\begin{array}{r}-0.403 \\
(-1.033)\end{array}$ & & $\begin{array}{c}0.113 \\
(0.152)\end{array}$ \\
\hline \# OF TRADES - PIT & & & $\begin{array}{c}-0.006 \\
(-0.528)\end{array}$ & & $\begin{array}{c}0.010 \\
(0.666)\end{array}$ & & $\begin{array}{l}0.056 \\
(1.198)\end{array}$ & & & & $\begin{array}{c}-0.005 \\
(-0.728)\end{array}$ & & $\begin{array}{c}0.003 \\
(0.200)\end{array}$ & & $\begin{array}{c}0.014 \\
(0.709)\end{array}$ & \\
\hline \# OF TRADES - E. FUTURES & $\begin{array}{c}0.009 \\
(0.702)\end{array}$ & & $\begin{array}{c}-0.021 \\
(-1.291)\end{array}$ & & $\begin{array}{c}0.070 \\
(3.470)^{* * *}\end{array}$ & & & & $\begin{array}{c}0.009 \\
(0.630)\end{array}$ & & $\begin{array}{c}-0.019 \\
(-2.132)^{* *}\end{array}$ & & $\begin{array}{c}0.045 \\
(2.129)^{* *}\end{array}$ & & & \\
\hline \# OF TRADES - CASH & $\begin{array}{c}0.038 \\
(3.577)^{* * *}\end{array}$ & & $\begin{array}{c}0.001 \\
(0.092)\end{array}$ & & $\begin{array}{c}0.027 \\
(1.747)^{*}\end{array}$ & & $\begin{array}{c}0.047 \\
(0.713)\end{array}$ & & $\begin{array}{c}0.027 \\
(2.259)^{* *}\end{array}$ & & $\begin{array}{c}0.007 \\
(1.030)\end{array}$ & & $\begin{array}{c}0.054 \\
(3.372)^{* * *}\end{array}$ & & $\begin{array}{c}0.009 \\
(0.318)\end{array}$ & \\
\hline PIT/E. FUTURES TRADE RATIO & & & & $\begin{array}{c}0.386 \\
(2.581)^{* *}\end{array}$ & & $\begin{array}{c}-0.106 \\
(-0.746)\end{array}$ & & & & & & $\begin{array}{c}0.143 \\
(1.742)^{*}\end{array}$ & & $\begin{array}{r}0.090 \\
(0.639)\end{array}$ & & \\
\hline FUTURES/CASH TRADE RATIO & & $\begin{array}{c}-0.137 \\
(-1.389)\end{array}$ & & $\begin{array}{c}-0.060 \\
(-0.384)\end{array}$ & & $\begin{array}{c}0.860 \\
(4.414)^{* * * *}\end{array}$ & & $\begin{array}{c}0.315 \\
(0.620)\end{array}$ & & $\begin{array}{c}-0.073 \\
(-0.669)\end{array}$ & & $\begin{array}{c}0.060 \\
(0.695)\end{array}$ & & $\begin{array}{c}1.116 \\
(5.759)^{* * * *}\end{array}$ & & $\begin{array}{c}0.203 \\
(0.928)\end{array}$ \\
\hline PIT FUTURES VOLATILITY & & & $\begin{array}{c}-0.043 \\
(-3.795)^{* * *}\end{array}$ & & $\begin{array}{c}0.029 \\
(2.075)^{* *}\end{array}$ & & $\begin{array}{c}-0.020 \\
(-0.631)\end{array}$ & & & & $\begin{array}{c}-0.018 \\
(-2.896)^{* * *}\end{array}$ & & $\begin{array}{l}0.024 \\
(1.588)\end{array}$ & & $\begin{array}{c}0.013 \\
(0.929)\end{array}$ & \\
\hline E. FUTURES VOLATILITY & $\begin{array}{c}-0.032 \\
(-2.072)^{* *}\end{array}$ & & $\begin{array}{c}0.003 \\
(0.261)\end{array}$ & & $\begin{array}{c}-0.005 \\
(-0.290)\end{array}$ & & & & $\begin{array}{c}-0.019 \\
(-1.139)\end{array}$ & & $\begin{array}{c}0.009 \\
(1.215)\end{array}$ & & $\begin{array}{c}-0.001 \\
(-0.078)\end{array}$ & & & \\
\hline CASH VOLATILITY & $\begin{array}{c}0.052 \\
(3.050)^{* * *}\end{array}$ & & $\begin{array}{l}0.015 \\
(1.431)\end{array}$ & & $\begin{array}{c}0.014 \\
(1.067)\end{array}$ & & $\begin{array}{l}-0.027 \\
(-0.776)\end{array}$ & & $\begin{array}{l}0.025 \\
(1.320)\end{array}$ & & $\begin{array}{l}0.005 \\
(0.834)\end{array}$ & & $\begin{array}{c}-0.011 \\
(-0.772)\end{array}$ & & $\begin{array}{c}-0.024 \\
(-1.608)\end{array}$ & \\
\hline PIT/E. FUTURES VOLATILITY RAT & & & & $\begin{array}{c}-0.266 \\
(-2.546)^{* *}\end{array}$ & & $\begin{array}{c}0.022 \\
(0.161)\end{array}$ & & & & & & $\begin{array}{c}-0.154 \\
(-2.685)^{* * * *}\end{array}$ & & $\begin{array}{c}-0.061 \\
(-0.446)\end{array}$ & & \\
\hline FUTURES/CASH VOL. RATIO & & $\begin{array}{c}-0.628 \\
(-7.708) * * *\end{array}$ & & $\begin{array}{c}-0.141 \\
(-1.522)\end{array}$ & & $\begin{array}{c}-0.346 \\
(-2.838)^{* * *}\end{array}$ & & $\begin{array}{l}-0.052 \\
(-0.248)\end{array}$ & & $\begin{array}{c}-0.463 \\
(-5.153) * * *\end{array}$ & & $\begin{array}{c}-0.005 \\
(-0.101)\end{array}$ & & $\begin{array}{c}-0.282 \\
(-2.327)^{* *}\end{array}$ & & $\begin{array}{c}0.031 \\
(0.343)\end{array}$ \\
\hline RSQ & 0.154 & $\begin{array}{l}0.197 \\
384\end{array}$ & $\begin{array}{l}0.097 \\
873\end{array}$ & $\begin{array}{l}0.033 \\
873\end{array}$ & $\begin{array}{l}0.219 \\
873\end{array}$ & $\begin{array}{c}0.084 \\
873\end{array}$ & -0.006 & $\begin{array}{c}-0.007 \\
0.01\end{array}$ & 0.060 & 0.102 & 0.054 & 0.033 & 0.092 & 0.042 & $\begin{array}{c}-0.007 \\
0.01\end{array}$ & -0.007 \\
\hline
\end{tabular}


Figure 1: Canadian Futures Market (CGB) Price Discovery Share Gonzalo-Granger Shares

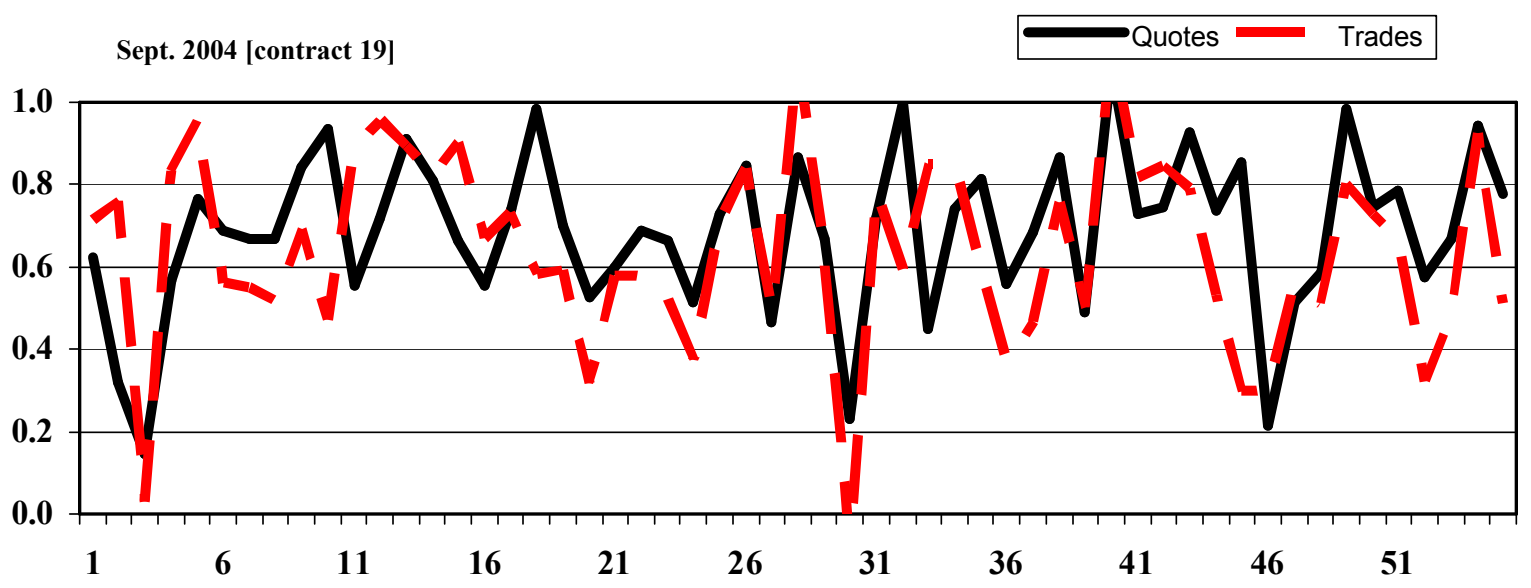

Figure 2: Canadian Futures Market (CGB) Price Discovery Share Gonzalo-Granger and Hasbrouck Shares

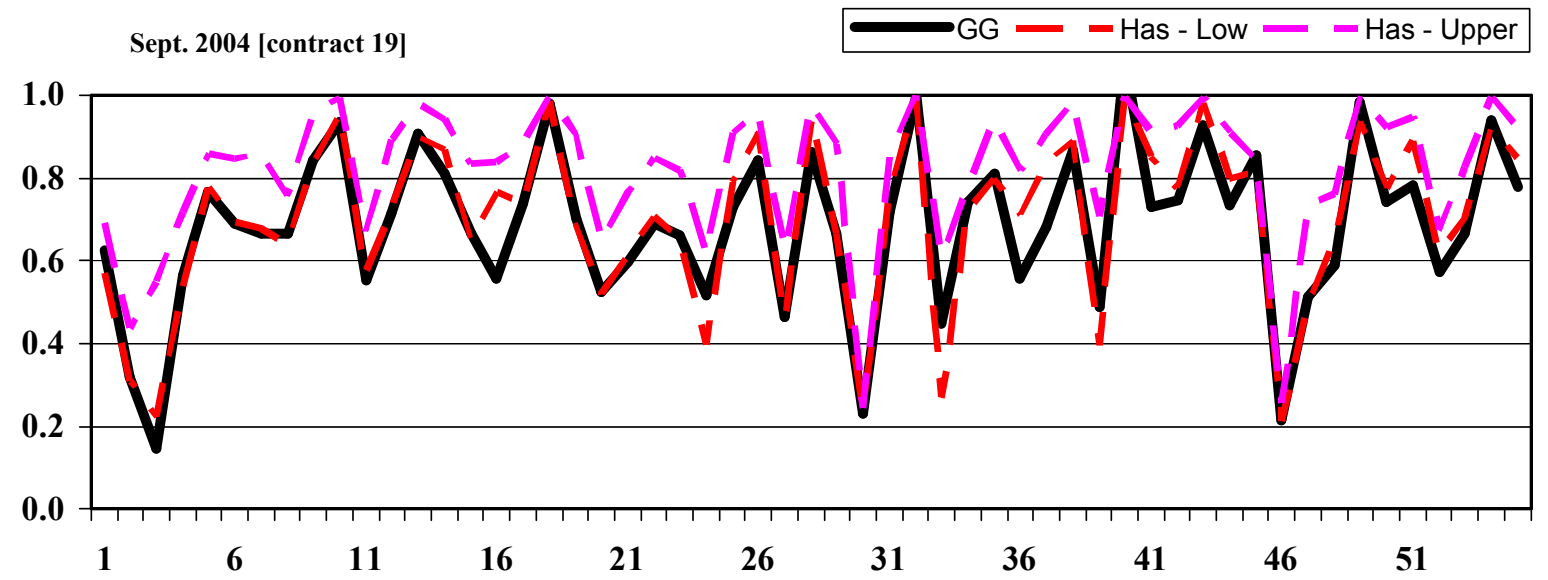


Figure 3: U.S. Futures Market Price Discovery

\section{Information Shares using GovPx data}

June 2000 [contract 1]

$G G=-$ Has - Low - Has - Upper

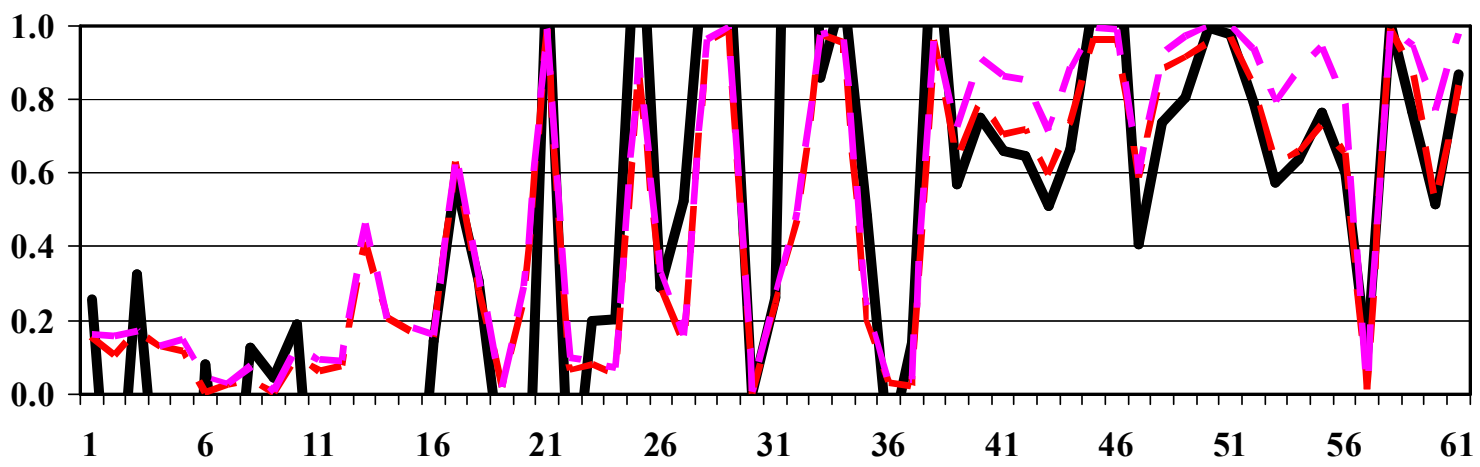

September 2000 [contract 3]

$\longrightarrow$ GG - Has - Low -- Has - Upper

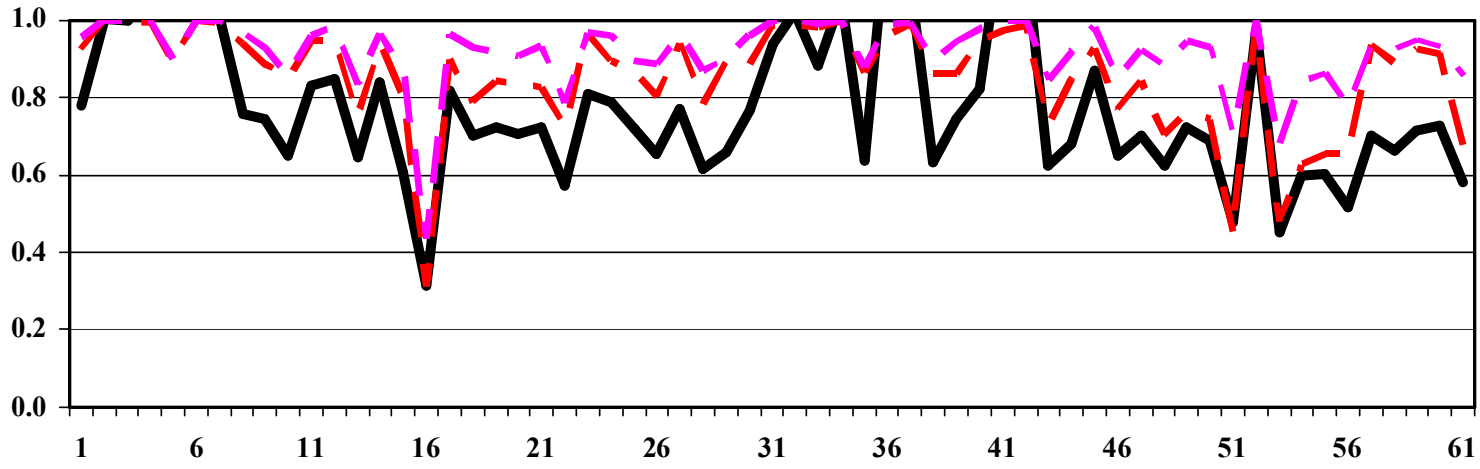


Figure 4: U.S. Futures Market Price Discovery Shares

March 2003 [contract 13]

- - GGfp $\rightleftharpoons$ GGFe

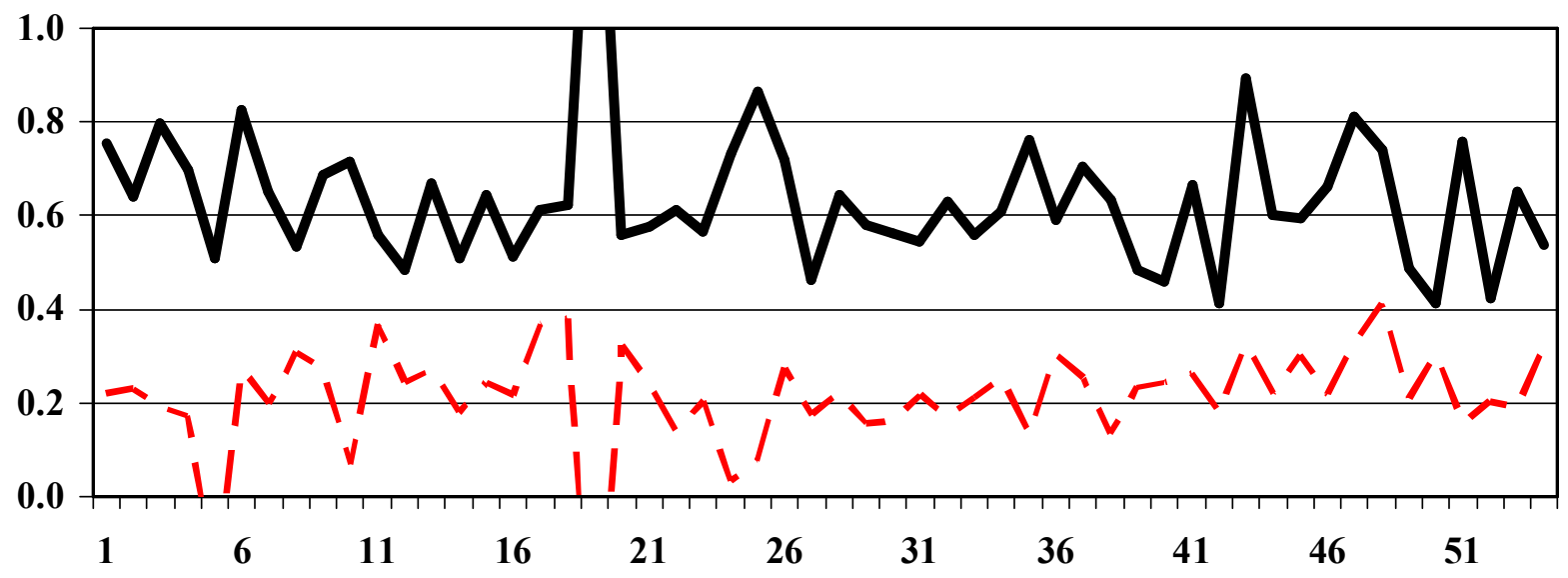

March 2004 [contract 17]

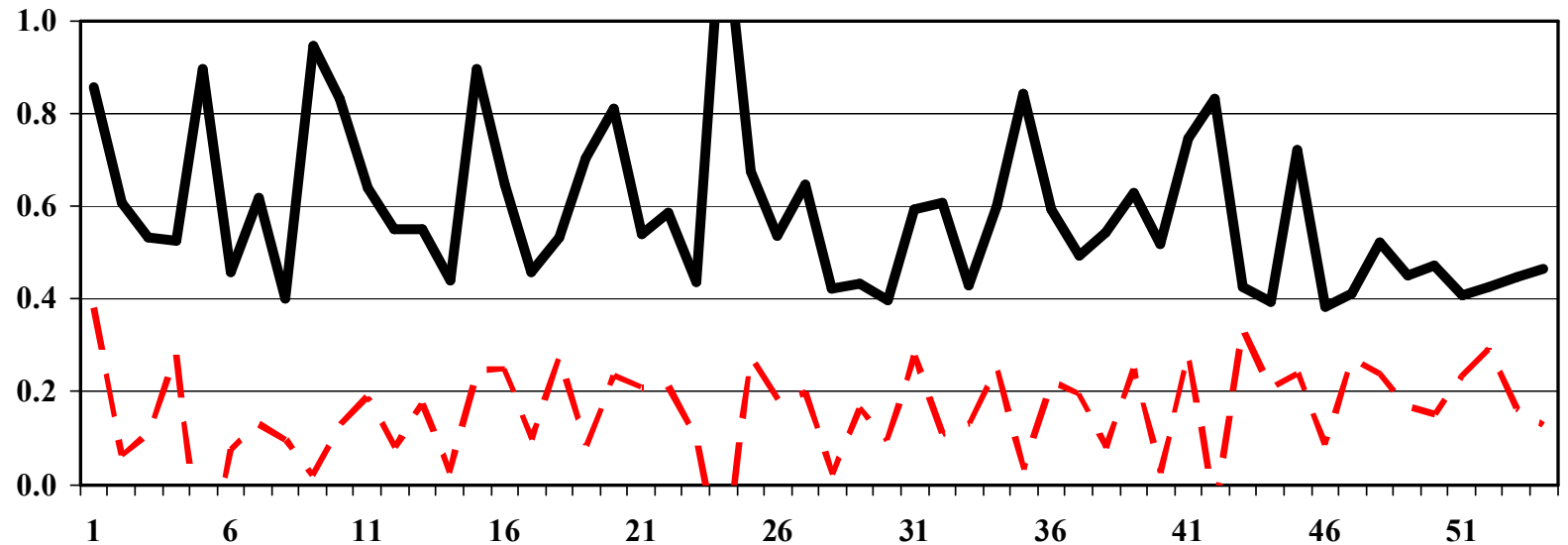

Dec. 2005 [contract 21]

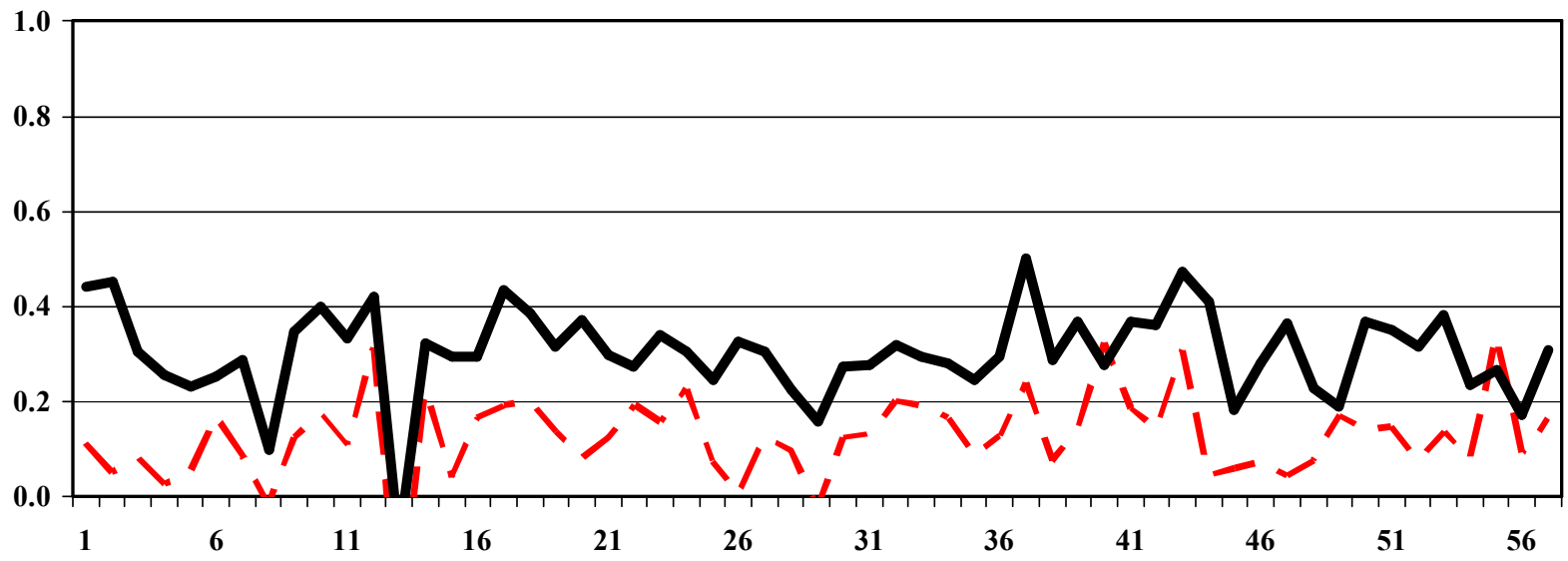


